\title{
Uma Revisão
}

\section{no Desenho dos Espaços}

Livres Urbanos dos Conjuntos

Residenciais do

"Urbanismo Moderno"

\section{Marcia Halluli Menneh}

Arquiteta urbanista e paisagista, mestre e doutoranda FAUUSP 
O artigo apresenta uma revisão no desenho do espaço livre que resulta da implantação dos edifícios dos grandes conjuntos habitacionais modernistas, incorporando as criticas que levaram a novas propostas nas áreas residenciais a partir dos anos 60, enfatizando as relações entre espaço livre e espaço construido, característico de cada modelo urbanistico apresentado.

Questiona o desenho dos espaços livres urbanos resultantes de intervenções calcadas nos principios do modernismo, apresentando exemplos que mostram: 1) a busca pela identidade dos espaços urbanos; 2) as recentes tendências européias como a retomada da quadra urbana tradicional e a preocupação com a hierarquização dos espaços livres; 3) a adaptação do modelo habitacional proposto pelo movimento moderno ao projeto dos conjuntos residenciais brasileiros, discutindo a forma de apropriação de seus espaços livres e, finalmente, as propostas habitacionais brasileiras recentes.

The article presents one revision of open space design that comes from the implantation of buildings in a big social housing projects from the Modern period, incorporating the criticism that lead to new proposals in residential areas from the 60's to nowadays, enphasizing the relationship between open space and constructed space.

It questions the design of urban open space that results from the Modernism principles, presenting exemples that shows: 1) the search for the urban space identity; 2) the recent european tendencies as the return of traditional urban square and the preocupation with the open space hierarchyzation; 3) the adaptation of the residential model proposed by the modern moviment to the project of brasilian social housing, discussing the way of open space utilization and, finally, the most recent brasilian residential proposals. 


\section{Uma Revisão \\ no Desenho dos Espaços \\ Livres Urbanos dos Conjuntos \\ Residenciais do \\ "Urbanismo Moderno"}

1

ntrodução

Com a Revolução Industrial, nasceu uma nova sociedade urbana, exigindo outras formas de se pensar o traçado e os espaços urbanos, uma vez que, em conseqüência de um crescente processo de urbanização, o antigo modelo de cidade não era compatível à essa nova realidade. A cidade industrial desenvolveu-se em ritmo bastante acelerado e a questão da habitação e das condições de vida das áreas urbanas passaram a figurar entre as principais preocupações dos urbanistas do início do século 20.

Foi em virtude desse contexto que surgiu, na Europa e nos Estados Unidos, a necessidade de intervenção do poder público para: solucionar os problemas advindos da acelerada urbanização, ordenar o crescimento das cidades, abrigar as grandes massas urbanas que se formavam e garantir condições mínimas de higiene. Por volta de 1850 , o urbanismo moderno ${ }^{1}$ dá os primeiros passos, por meio das propostas dos técnicos e higienistas, que se esforçam em remediar os problemas da cidade industrial, através de projetos que visam o embelezamento e a modernização das cidades.

As intervenções urbanas dos setores públicos ou privados, no campo do urbanismo, realizam-se tanto por meio de projetos que levam à expansão da mancha urbana, como dos que se propõem a redesenhar

(1) Utiliza-se aqui o termo urbanismo moderno, sem a pretensāo de precisar seu início efetivo e sim como o início das intervenções no espaço físico, onde já se encontram algumas das preocupaçōes que caracterizam o urbanismo moderno. A fase onde se discutiu a cidade industrial lainda no campo da sociologia urbanal foi, propositadamente, deixada de lado. 
os espaços existentes, para adaptá-los às novas necessidades. Foram enfocados os problemas da habitação da classe trabalhadora e os referentes à forma de vida na cidade, relativos tanto à circulação e à necessidade de equipamentos urbanos e comunitários, como à localização das diferentes atividades, especialmente os relacionados aos locais de trabalho e de moradia.

Verifica-se que muitas das questões, que tiveram início nesse período, tais como a habitação social, a expansão das cidades e a necessidade de renovação das áreas centrais (que visam acompanhar a transformação das necessidades e conseqüentes transformações das atividades, características de cada momento históricol, permanecem sem solução até os dias de hoje. Confirmam esta observação os seguintes trechos da palestra de Anatole Kopp ${ }^{2}$ :

".... quando se observa mais atentamente, nota-se que estes problemas continuam presentes e a 'Modernidade' tal como foi concebida, ao longo dos anos do pós-guerra la primeira naturalmente) é, ainda, em muitos de seus aspectos, a 'Modernidade' de hoje - se não pelas respostas que ela preconizava, mas por questões colocadas e que ainda se revelam atuais. ... o 'Moderno' nasceu como resposta a uma situação histórica. O 'Moderno' na arquitetura é um momento da história, uma tomada de posição permanente fundada em princípios e métodos estabelecidos com relação aos problemas de seu tempo e apoiando-se no desenvolvimento científico e técnico mais avançado e na análise das necessidades e das possibilidades que a sociedade tinha para satisfazê-las. É com este sentido que o 'Moderno' poderia existir hoje - apesar dos efeitos contrários da moda..."3

Com esse tipo de abordagem é utilizado, nesse trabalho, o termo urbanismo moderno e partindo desse enfoque discorre-se sobre os parâmetros que nortearam o movimento moderno na arquitetura e no urbanismo.

(2) KOPP. Anatole. Modernismo hoje (tradução e notas de Reginaldo Forti sobre a palestra "Modernisme Ajourd 'hui"). Revista AU, dez. e jan. de 86/87, São Paulo: Pini, p. 88 a 92.

(3) KOPP, Anatole. Modernismo hoje (tradução e notas de Reginaldo Forti sobre a palestra "Modernisme Ajourd'hui"). Revista $A U$, dez. e jan. de 86/87, São Paulo: Pini, p. 88 e 92.

\begin{tabular}{|c|c|c|}
\hline 44 & Paisagem & São Paulo n. 11 p. $41 \quad 70$ dez. 1998 \\
\hline & $\begin{array}{l}\text { Ensaios } \\
11\end{array}$ & \\
\hline
\end{tabular}


Se por um lado, o urbanismo moderno já encontra no final do século 18, com o surgimento da cidade capitalista, condiçōes para seu desenvolvimento enquanto atividade profissional, deve-se observar que ele só se firma mais tarde como uma atividade exercida por arquitetos. Isso ocorre, principalmente, após a Primeira Guerra Mundial, uma vez que no período compreendido entre as duas guerras surgem os primeiros projetos sociais, as diferentes correntes culturais e os movimentos políticos, que deram origem às principais idéias que caracterizam a arquitetura moderna.

Foram elaborados, nas décadas de 20 e 30 na Europa, os modelos teóricos que vão constituir a base do chamado movimento moderno na arquitetura e urbanismo. Ao se estudar os conceitos que nortearam os modelos elaborados pelo movimento moderno na arquitetura e urbanismo, busca-se as bases que fundamentaram a legislação urbanística, que passou a vigorar em vários países, no período subseqüente, após a consolidação dos modelos urbanísticos propostos.

Nesse sentido, esse trabalho apresenta exemplos do urbanismo moderno com o intuito de extrair aspectos relevantes que tiveram papel determinante no desenho urbano de diferentes setores da maior parte das cidades capitalistas. A ênfase é dada às relações entre espaço livre e espaço construído, característicos de cada modelo urbanístico apresentado e aos resultados da aplicação destes na transformação e nas formas de apropriação dos espaços livres.

Este artigo discute, portanto, a edificação e os espaços livres dos conjuntos habitacionais verticalizados modernos e contemporâneos, identificando os seus padrões espaciais, a volumetria construída e suas formas de implantação no lote dentro de uma perspectiva histórica.

O desenho da paisagem urbana moderna é um tema ainda não esgotado pelos estudos e pesquisas já realizados, devendo-se discutir os parâmetros de desenho para os diferentes projetos urbanos que caracterizam a produção e a transformação do espaço em seus vários aspectos, visando instrumentar os projetos de renovação urbana que passaram a ocupar o cenário urbanístico internacional nos últimos anos. 


\section{- questionamento acerca do desenho da paisagem resultante da implantação dos grandes conjuntos habitacionais modernistas europeus}

Os projetos de renovação urbana têm se sucedido na Europa e Estados Unidos, especialmente após o início da revisão dos parâmetros de desenho urbano impostos pelo movimento moderno. No Brasil, apesar dessa crítica também ter se instaurado, acabou valorizando temas como: a construção de Brasília e os projetos de conjuntos residenciais resultantes da política habitacional do Banco Nacional de Habitação - BNH.

Observa-se que a revisão dos conceitos referentes aos modelos que resultaram do movimento moderno não levou a alterações substanciais nos padrões urbanísticos adotados no Brasil. Para isso contribuíram vários fatores, sendo os principais: o déficit habitacional brasileiro não foi superado e o momento em que essa discussão foi deflagrada, na Europa e nos Estados Unidos, coincide com o início da crise econômica brasileira, que permanece ainda hoje.

A crítica ao modelo da Carta de Atenas já tinha tido início na Europa nos anos 50, apesar de muitos dos grandes conjuntos habitacionais "modernistas" europeus terem sido construídos nos anos 60. Observase, ainda, que a lei de zoneamento da cidade de São Paulo foi elaborada no final da década de 60 e implantada somente em 1972, justamente quando as críticas do movimento moderno se propagaram na Europa e Estados Unidos 4

Entre os fatores desencadeadores dessa crítica, cita-se o fato da crise habitacional européia do período pós-guerras já ter sido praticamente superada, permitindo que os políticos e urbanistas propusessem intervenções com o intuito de reestruturar o espaço construído, interferindo em estruturas urbanas existentes, o que implicou numa reavaliação das relações entre tipologia e morfologia urbana.

(4) Entre as críticas deste período, pode-se citar dois textos, amplamente divulgados: A morte $e$ a vida nas grandes cidades americanas, livro de Jane Jacobs, publicado em 1961, que critica vários conceitos consagrados do modernismo como: o desaparecimento da rua tradicional, a baixa densidade das cidadesjardins e as áreas verdes resultantes da forma de implantaçāo dos edifícios, onde o verde público se traduzia num vazio no meio dos edifícios; e $A$ cidade não é uma árvore, de Cristofer Alexander, publicado em 1965. um texto curto, que combate o funcionalismo, o zoneamento e a unidade de vizinhança. 
Além disso, os movimentos de lutas urbanas na Europa passam a reivindicar maior participação nas decisões referentes aos problemas das cidades, reagindo aos processos indesejados como: as intervenções de grande porte no tecido urbano, que destruíam importantes espaços, os quais propiciavam formas de organização social, consideradas importantes pela comunidade. Com isso, as esferas políticas percebem que os programas de intervençōes dessa ordem, desgastavam os partidos.

Começa-se a questionar sobre as torres habitacionais, pois apesar de mais fáceis de se construir em larga escala, não são necessariamente mais econômicas e nem sempre atingem maiores densidades de ocupação. Outro ponto importante é que os grandes conjuntos residenciais sofrem processos rápidos de deterioração. $O$ aumento da classe média na Europa, que configura uma sociedade de consumo com novas necessidades, contribuiu com a revisão dos padrões urbanísticos até então adotados, motivando maior preocupação com a qualidade dos empreendimentos habitacionais (investimentos públicos e privados).

Critica-se os superblocos, pois levam à descontinuidade da trama urbana, em função do tamanho e isolamento dos elementos urbanos do projeto modernista (Figuras 1 a 6). Nesses projetos, transformou-se o conceito de espaço público que, anteriormente, configurava-se como parte integrante da concepção de cidade. A “cidade dos blocos isolados" leva, portanto, a uma descodificação do espaço público, assim como das relações sociais, que neles tinham lugar. Privilegiando a circulação - isto é, ruas e avenidas, em detrimento das praças - o urbanismo moderno acabou levando a um esvaziamento dos significados políticos e culturais dos espaços públicos.

A seguir são apresentados alguns exemplos de grandes conjuntos residenciais modernistas da década de 60: Märkishes Viertel (1963-76) com 45.000 habitantes, em Berlim na Alemanha e Bijlmermeer (196777), com 50.000 habitantes, em Amsterdam na Holanda. Foram incluídos também conjuntos suíços das cidades satélites de Genebra, como Le Lignon (1963-67) e Avanchet (1969-77).

As ilustrações do conjunto Märkishes Viertel (Figuras 1 e 2) e Bijlmermeer (Figura 3) mostram claramente os conceitos modernistas, objeto da crítica dos teóricos da época: apesar da busca da diversidade

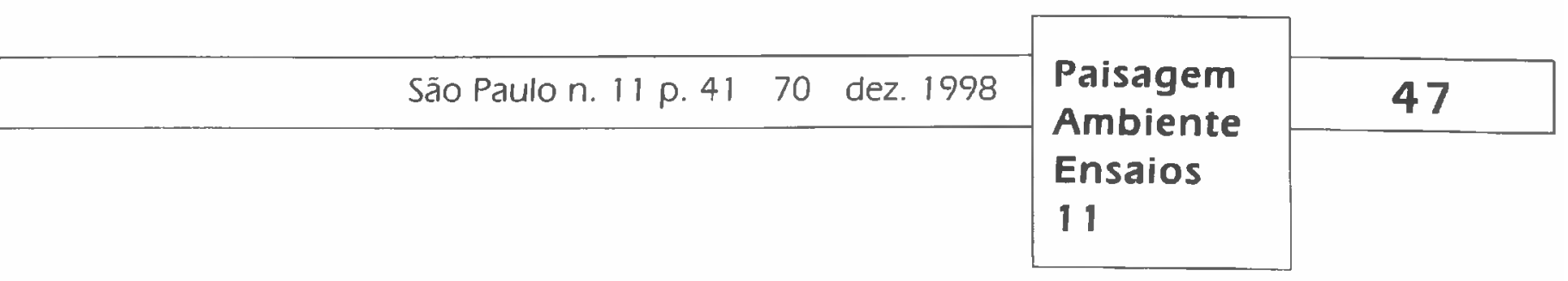


Marcla Uma Revisão no Desenho dos

Halluli Espaços Livres Urbanos dos

Menneh Conjuntos Residenciais do

"Urbanismo Moderno"

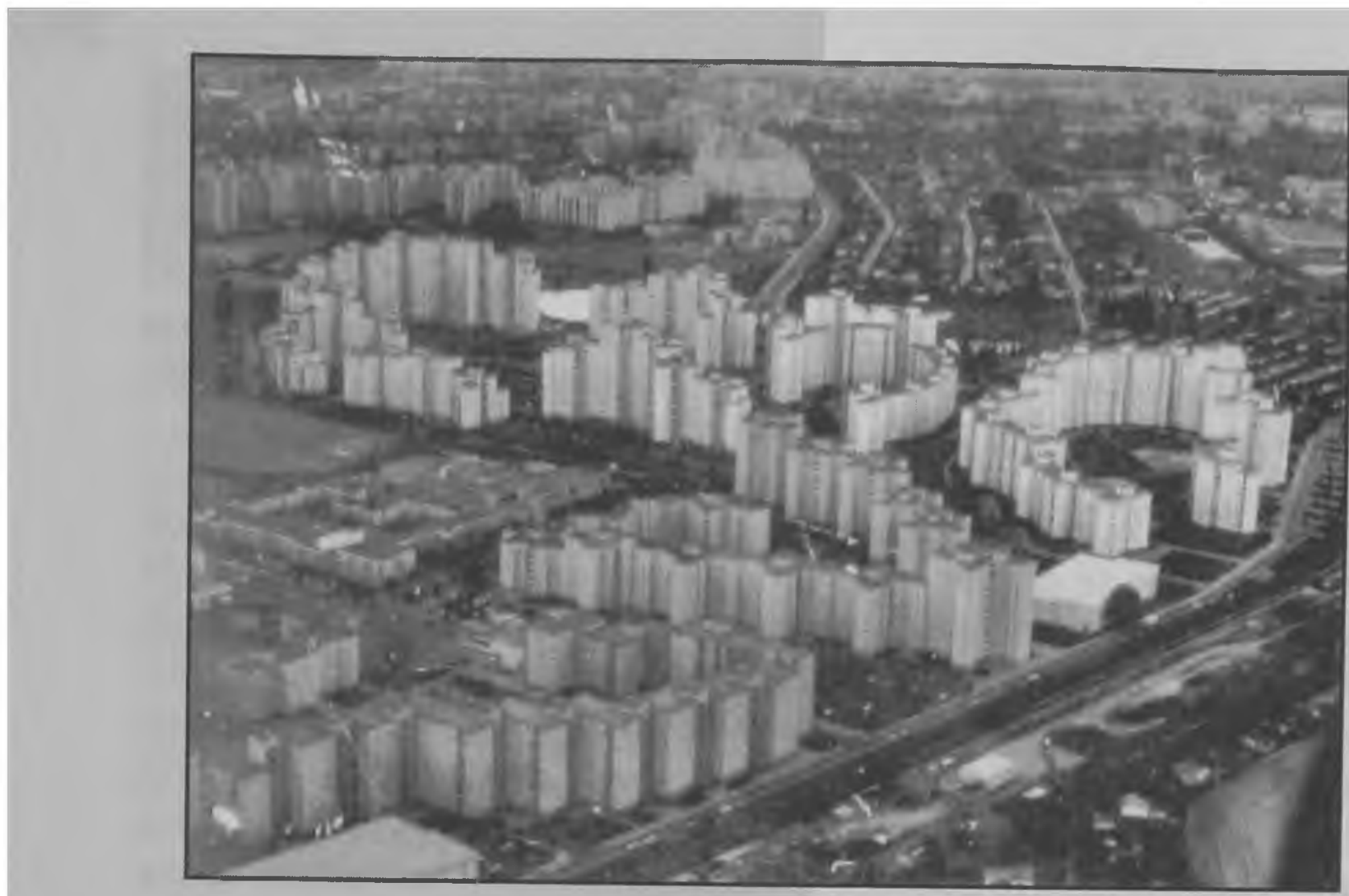

Figura 1: Märkisches Viertel, Berlin - Alemanha (1963)

Fonte: IBAVDokumente ProjeKte 1 - Modelle für eine Stadt, Berlin: Die Neubaugebiete, Siedler Verlag, 1984, 0.35

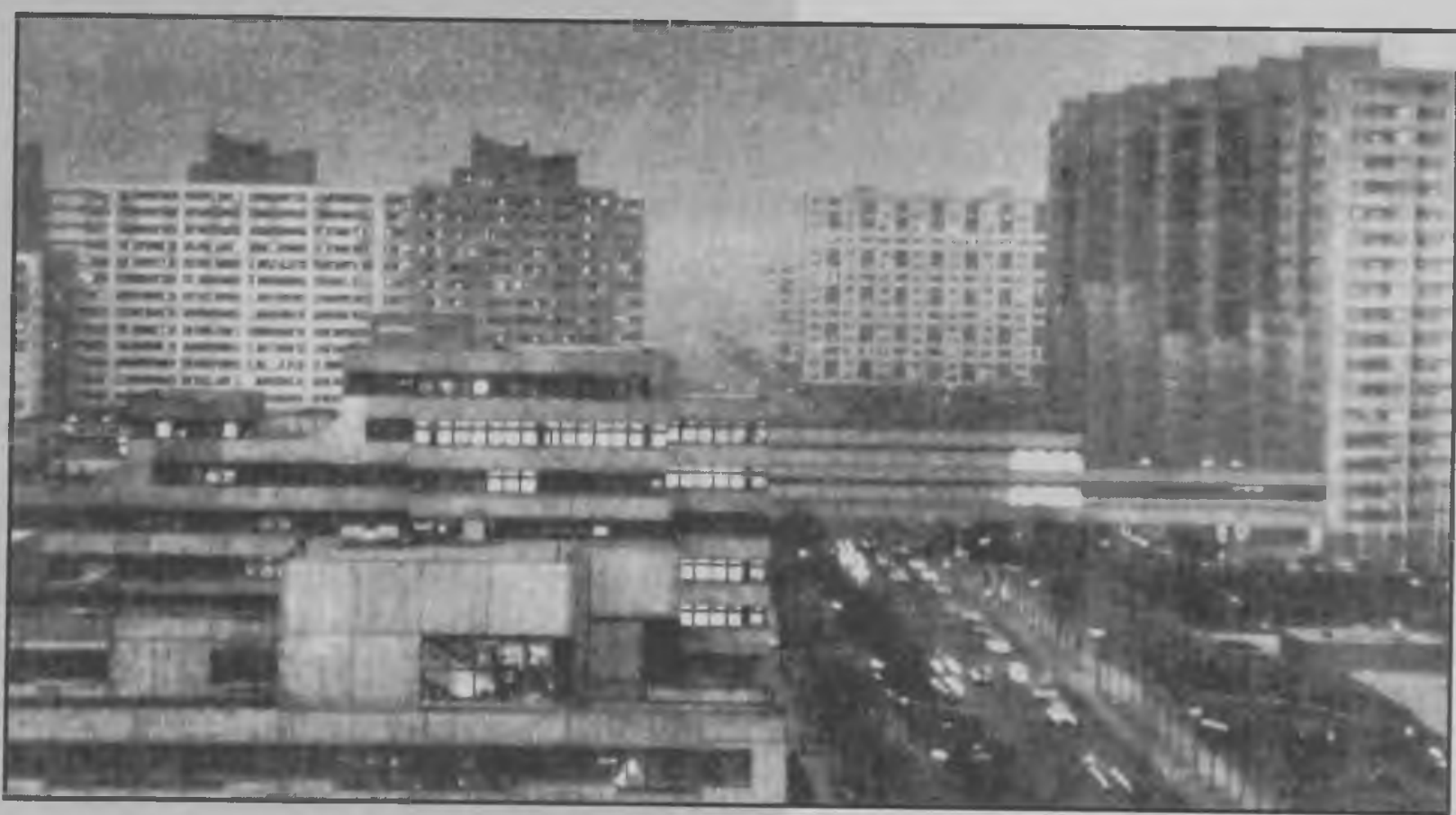

Figura 2: Märkisches Viertel

Fonte: Werk Archithese - Grossüberbauungen. Zurique: Verlag Arthur Nigli AG. n. 5, maio de 1977. p. 36

Comentário:

Apesar do desenho formado pelos edifícios, na escala pedestre verifica-se uma paisagem monótona e repetitiva, agravada pelo tamanho do conjunto. Ressalta-se ainda a ênfase no sistema viário. 


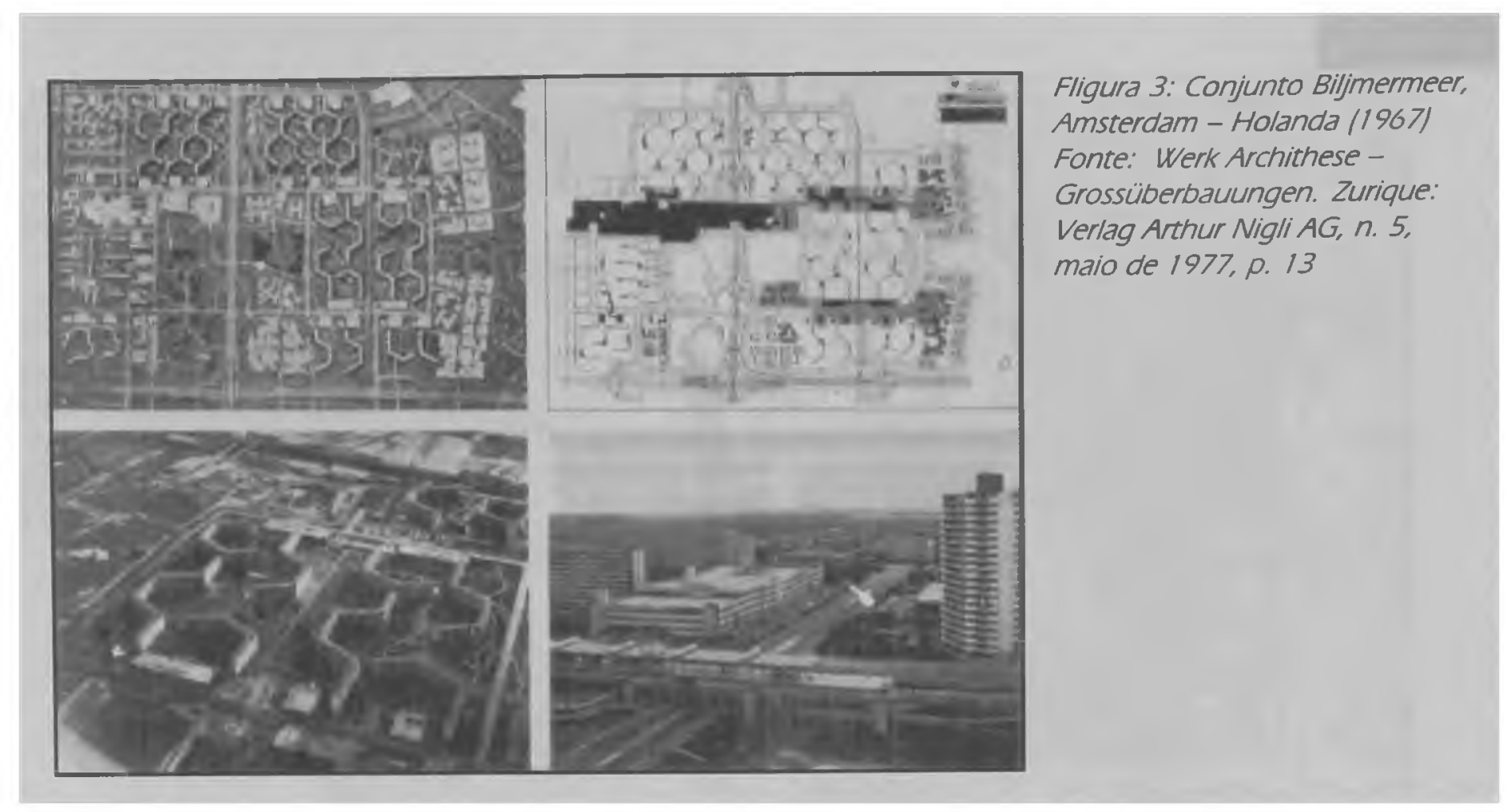

na forma de implantação, verifica-se, na escala do pedestre, dificuldade na identidade e legibilidade do espaço resultante. Além disso, os grandes espaços livres resultantes, destinados às áreas verdes são de difícil apropriação em função do porte.

O mapa da cidade de Genebra (Figura 4), mostra o porte deste tipo de intervenções, especialmente, quando consideradas no conjunto da cidade.

Se a aplicação do método de projeto proposto pelo movimento moderno foi inicialmente aplicado a alguns blocos habitacionais, situados em setores urbanos mais periféricos, estes exemplos (Figuras 1 a 6) mostram como esta escala de intervenção se alterou, dando origem às políticas de construção de grandes conjuntos habitacionais, que acabaram sendo substituídas, na Europa, pela de criação de "cidades novas"

Refletindo sobre as soluções apresentadas, com intuito de avaliar os padrões desejáveis de desenho urbano e a importância das relações visuais de cada paisagem urbana, discute-se os impactos paisagísticos e ambientais dessas intervenções, como também a perda da escala humana e a excessiva unidade entre os edifícios dos conjuntos, o que reduz a identidade de cada morador com sua moradia. 


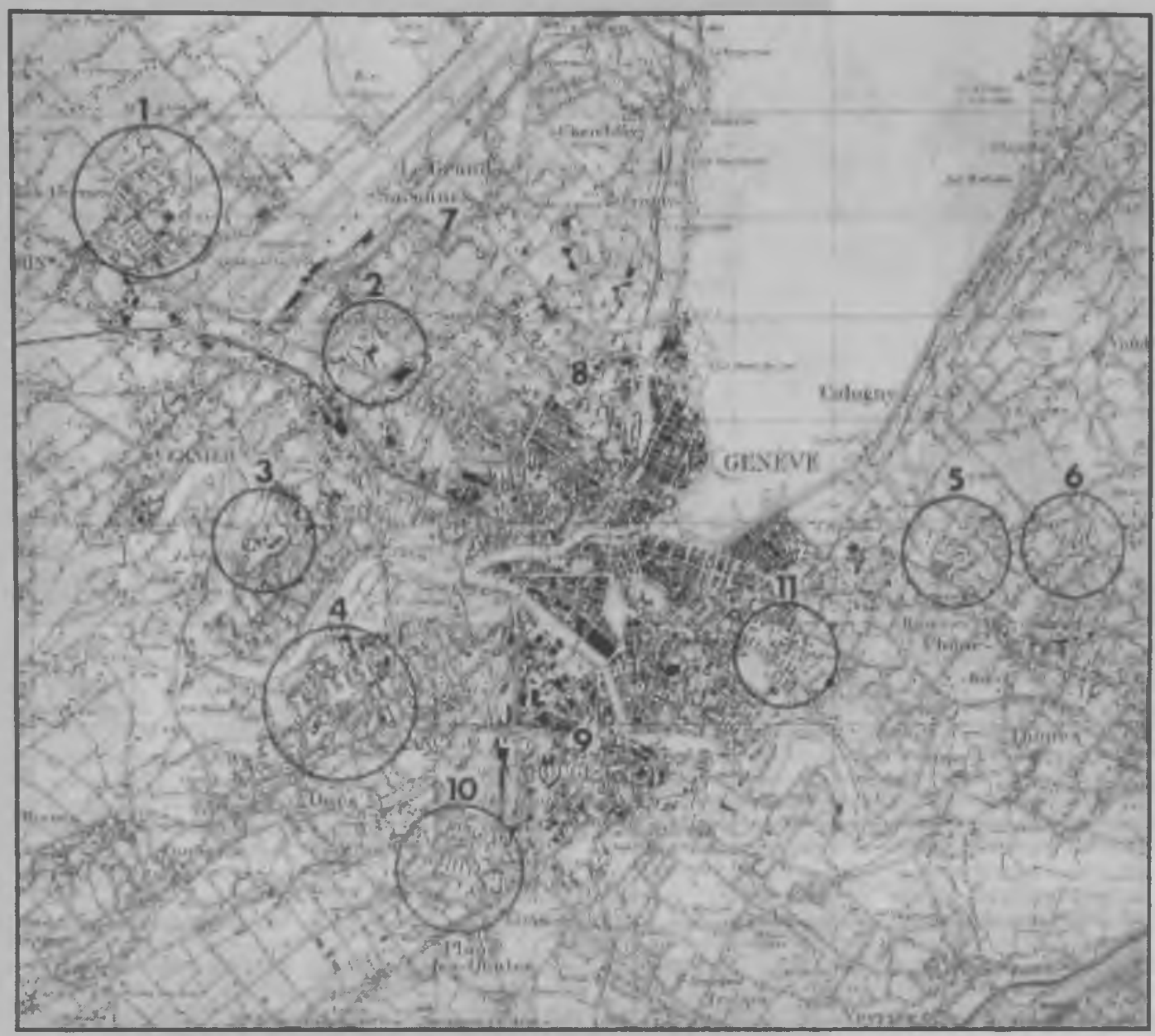

Figura 4: Conjuntos residenciais de grande porte e cidades satélites de Genebra

Fonte: Werk Archithese -

Stadtsanierung, Zurique: Verlag Arthur Nigli $A G$, n. 15-16, mar.) abr. de 1977, p. 26

Cidades satélites: 1. Meyrin, 2.

Avanchet, 3. Le Lignon, 4. Onex 5. La gradele 6. Bel-Air. Grandes conjuntos: 7. Saconnex, 8. Vermont, 9. Tous de Carouge, 10. Grand Lancy

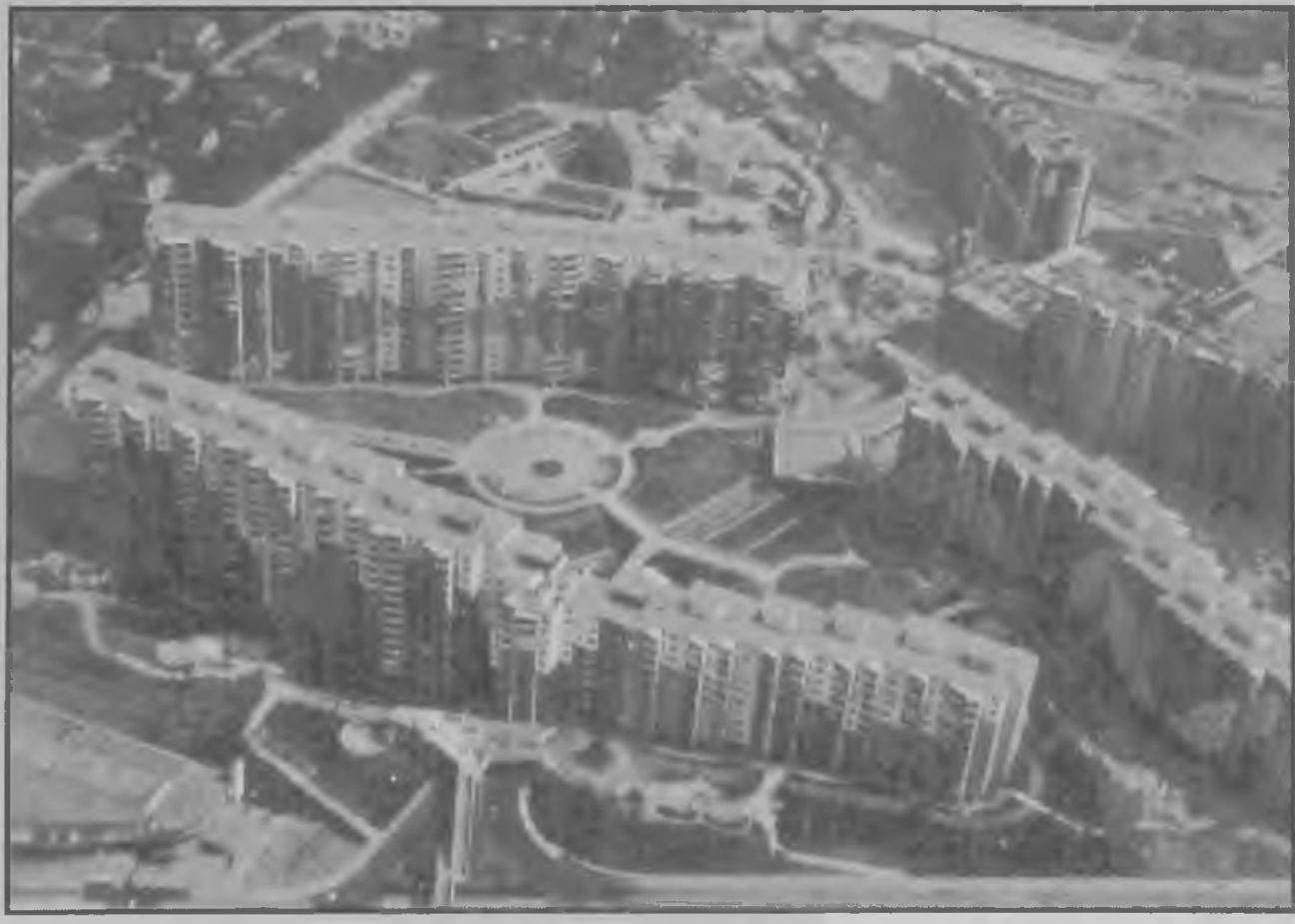

Figura 5: Avanchet-

Parc, Vernier,

Genebra

Fonte: Werk

Archithese -

Stadtsanierung.

Zurique: Verlag Anthur Nigli $A G . n$. 15-16, mar.abr. de $1977,0.27$

Comentario:

Nas fiquras 5 e 6 , percebe-se a tentativa de desenhar o espaço livre, mas o mesmo apresenta uma escala, onde é difícil a apropriação do espaço resultante.

\section{Paisagem Ambiente Ensaios




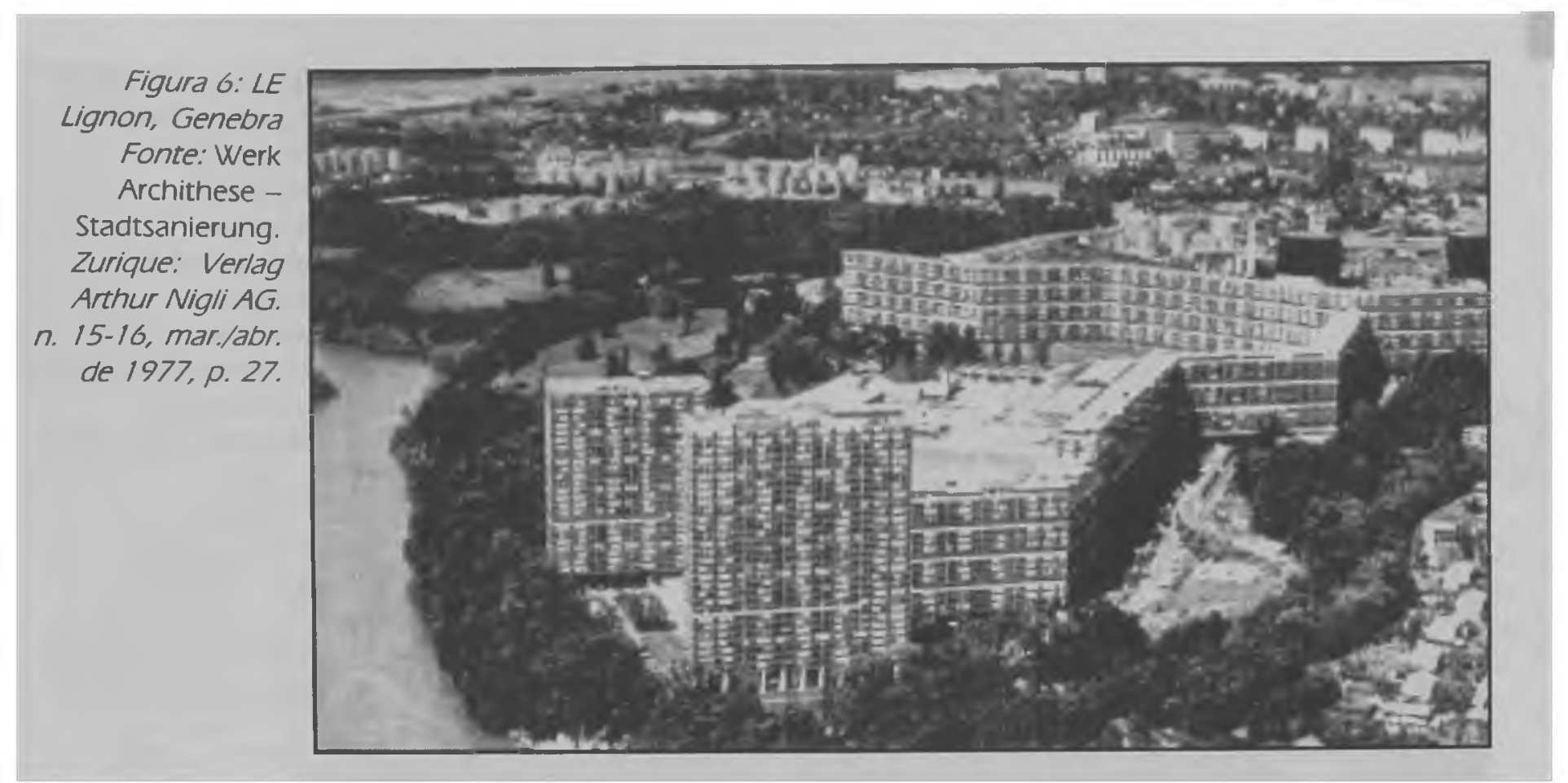

A desconsideração às condições locais, seja com relação ao relevo, à tipologia do entorno das áreas projetadas ou aos condicionantes sócioculturais da população do lugar (Figura 7), é uma crítica que comparece também no seguinte trecho de Bernard Huet: "A terminologia abstrata, instaurada pela Carta de Atenas tem uma função determinada na destruição da idéia de cidade: ao substituir uma palavra por outra ('alojamento' em vez de 'habitação' 'percurso' em vez de 'rua' 'espaço verde' em vez de 'parques' e 'jardins') ... a cidade se reduz a um invólucro que não contém mais nada." 5

Datam desse período as reflexões a respeito do sentido de lugar e das possibilidades de identificação visual e legibilidade dos espaços urbanos las cidades contemporâneas foram consideradas ininteligíveis). Inicia-se, com isso, a revisão das tipologias edificatórias utilizadas nas décadas anteriores, como os enormes blocos isolados e soltos na paisagem, revendo as densidades atingidas nos setores da cidade onde eles se situavam.

Algumas propostas começam a rever alguns dos conceitos modernistas, buscando maior identidade e legibilidade para os espaços urbanos, como por exemplo, os projetos de Lucien Kroll para a Universidade de Woluwé-Saint Lambert, realizados entre 1970-82 na Bélgica (Figuras 8 a 10).

(5) HUET, Bernard. A cidade como espaço habitado (alternativas à Carta de Atenas). Revista AU, dez./jan. 86/87, p. 84 . 
Marcia

Halluli

Menneh

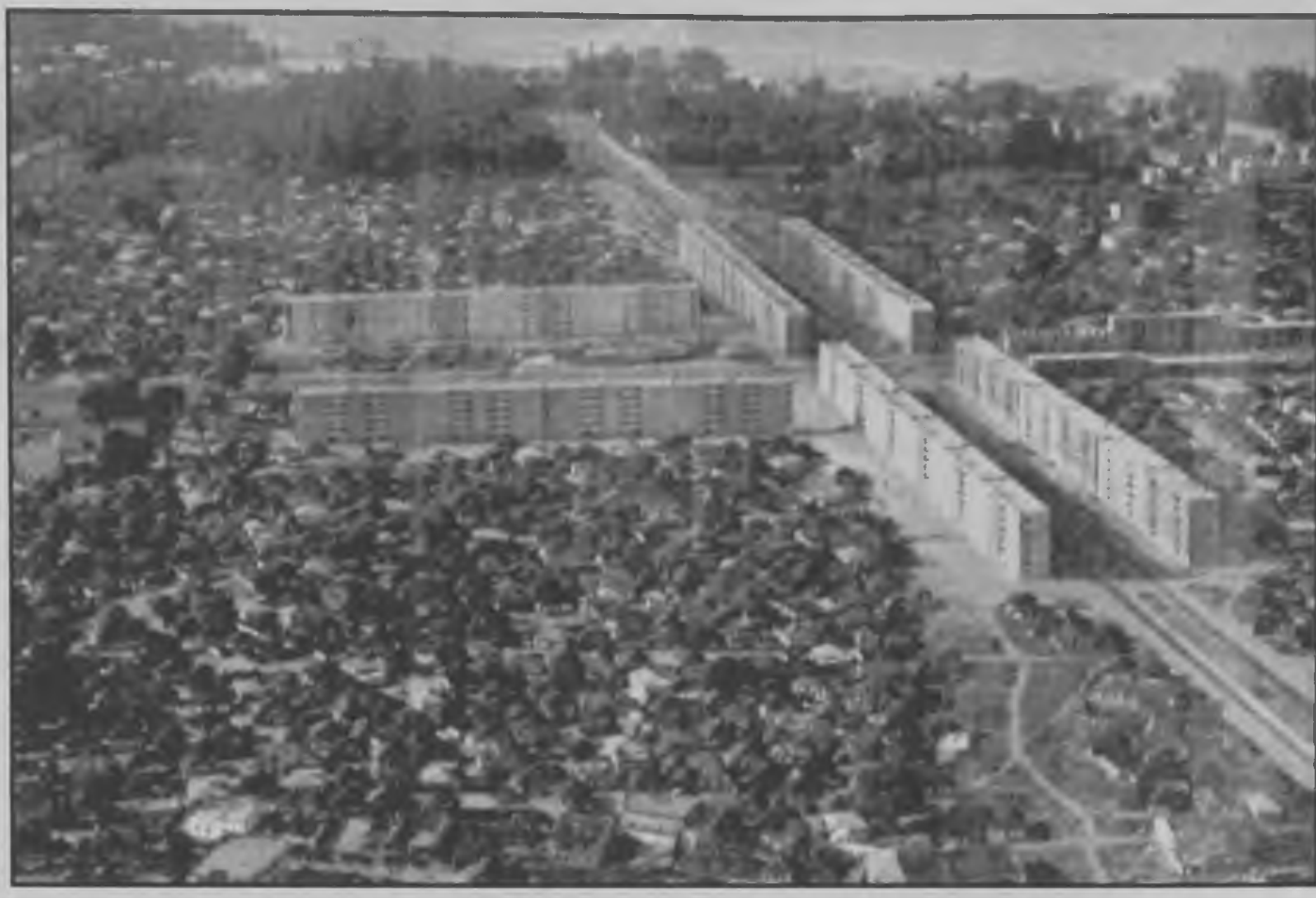

Figura 7: Cidade de Zanzibar, Tanzânia Fonte Werk Archithese "Meccano"?, Verlag Arthur Nigli AG. Zurique, n. 11-12, nov./dez. de 1977, $\rho$ 63 /também publicada por Nacional Geografic, abr. 1975).

Comentário:

Exemplo típico de projeto, onde a proposta de abertura das avenidas e construção dos edifícios desconsiderou as características do entorno e as tradiçōes locais.

Na Figura 8, ressalta-se a forma de implantação dos edifícios. Deve-se notar, ainda, as formas das fachadas dos edifícios. Além da diversidade nas formas, estas receberam também tratamento diferenciado, apresentando variação nas cores e materiais.

A monotonia é característica combatida em todas as fases do projeto, que busca maior identidade em cada espaço projetado, através do desenho de uma paisagem rica e diversificada. Para isso, utiliza-se do projeto cuidadoso dos edifícios e dos espaços livres. As fotos revelam o cuidado com os detalhes de projeto, com o intuito de criar espaços criativos e diversificados.

Outra proposta que busca identidade e redesenho da paisagem é o projeto do conjunto residencial de Piet Blom em Rotterdam, Holanda (Figura 11). O conjunto foi construído como uma ponte, sobre uma avenida de trânsito intenso, com um estacionamento subterrâneo abaixo da avenida. Também fazem parte do projeto alguns estabelecimentos comerciais e um centro comunitário, localizados junto à área coletiva de acesso aos apartamentos. 


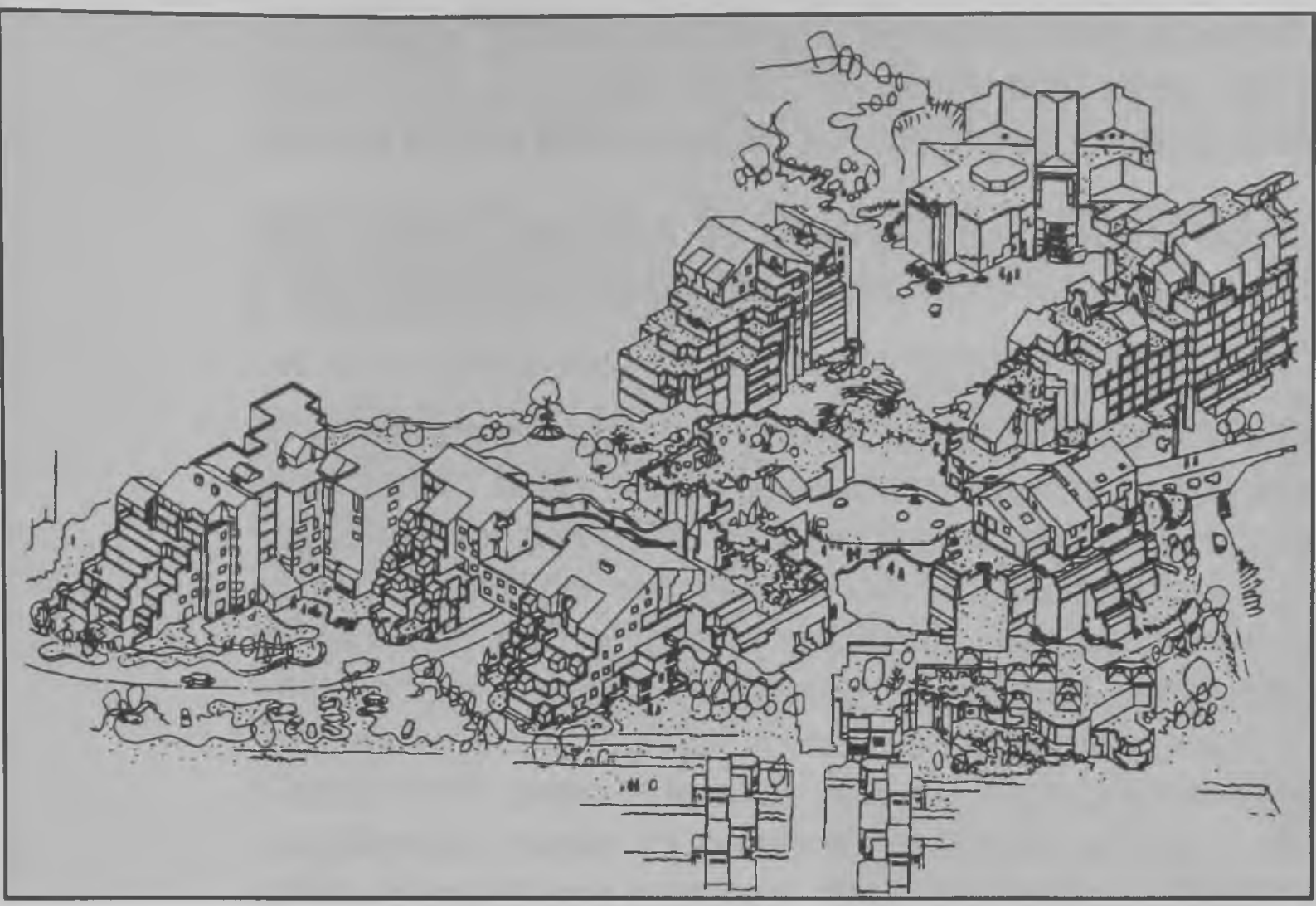

Figura 8: Woluwé-

Saint Lambert, Bélgica Lucien Kroll, 1970.

Perspectiva

Fonte: KROLL, Lucien. Buildings and projects. Rizzoli, Nova York, 1987, 0. 41

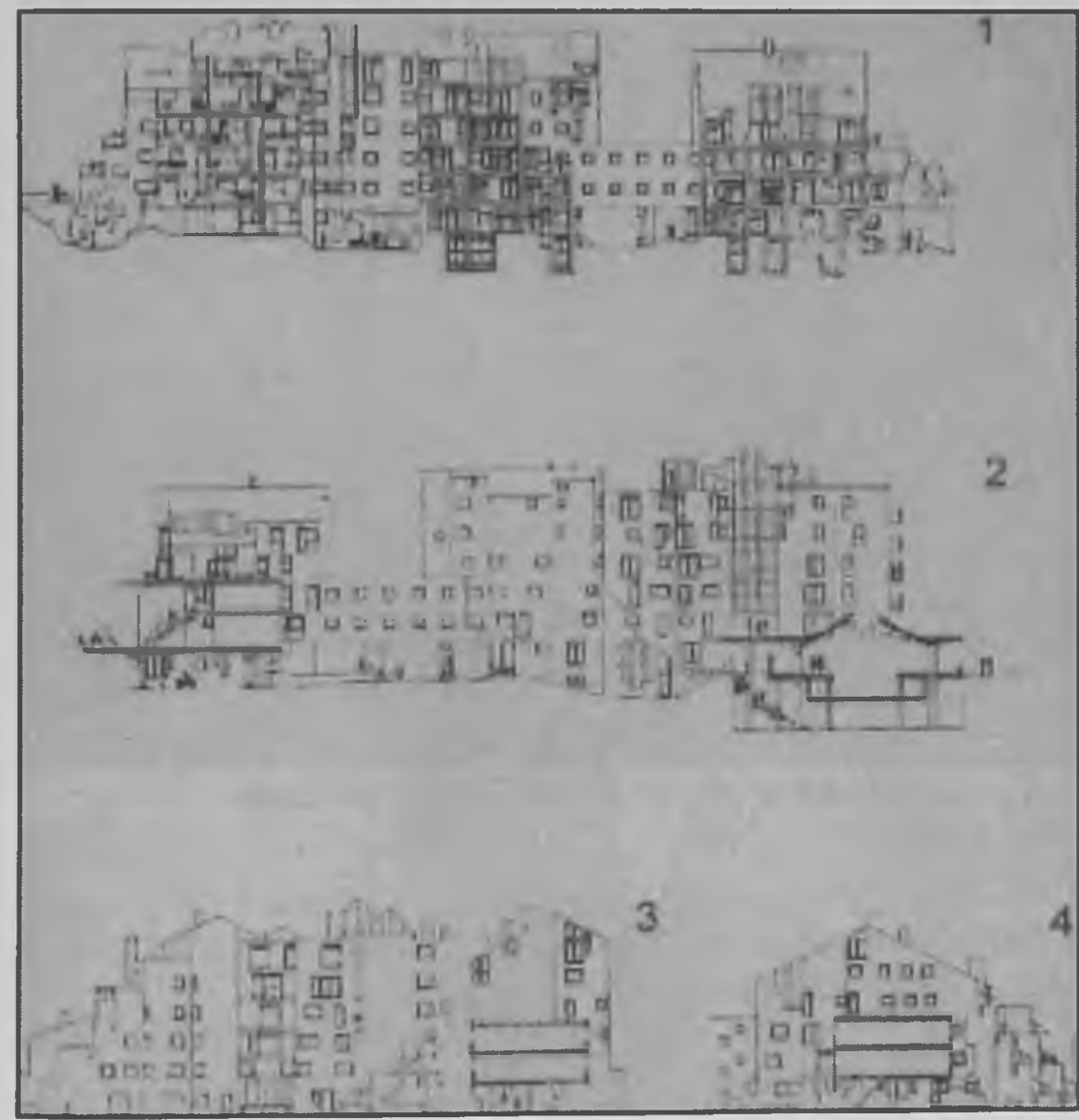

Figura 9: Woluwé-Saint Lambert - Vistas

Fonte: SUMMARIOS - "La Anarquitetura de Lucien Kroll", In:

Collección Summarios, n. 33, Buenos Aires: Edicionnes Summa, jul. de 1979, p. 83

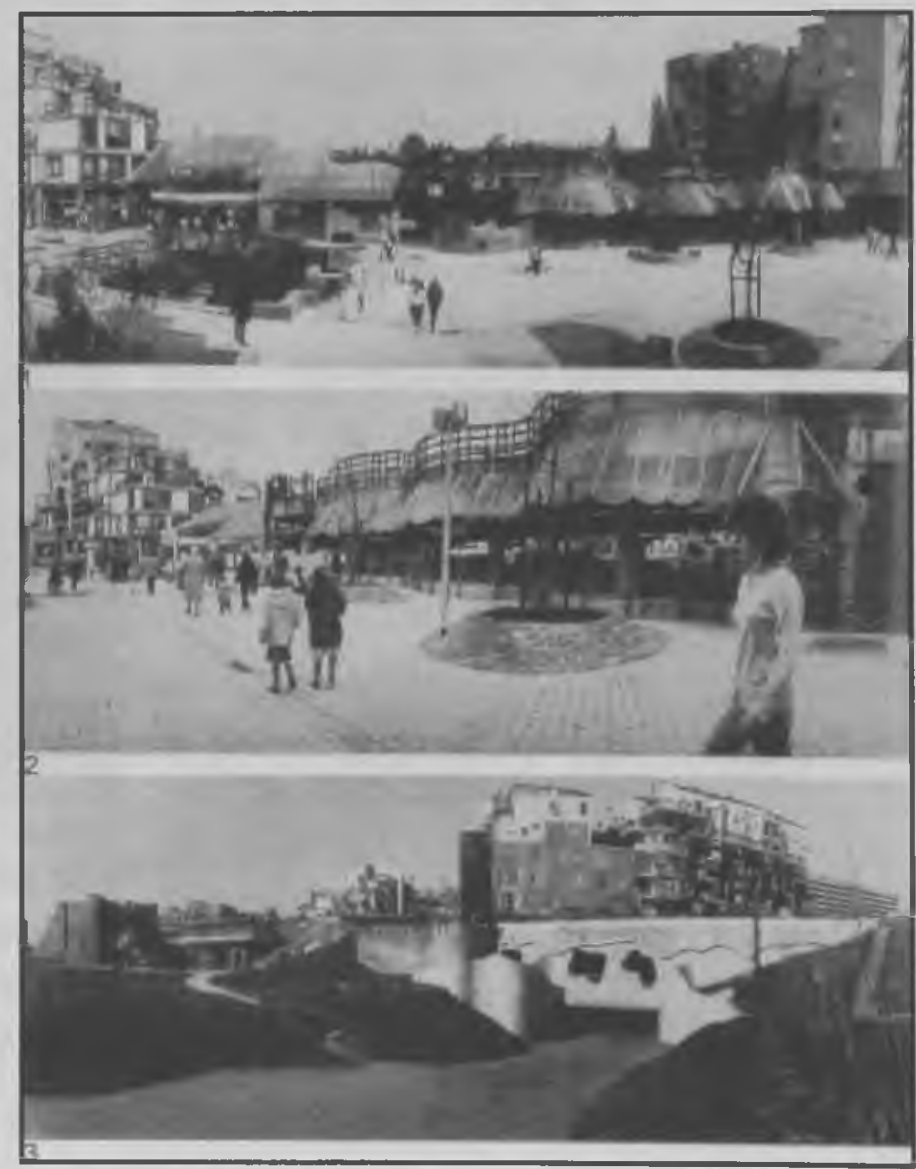

Figura 10: Woluwé-Saint Lambert, Bélgica - Lucien Kroll, 1970

Fonte: KROLL, Lucien. Buildings and projects. Nova York: Rizzoli, 1987, p. 68 
Em função destes questionamentos, a partir dos anos 60 , observou-se a retomada das idéias urbanísticas de Camilo Sitte 6 , o que vai alterar radicalmente as posturas de projeto nas décadas de 80 e 90 na Europa.

Os trechos que seguem, de Monteiro de Andrade ${ }^{7}$ fazem referência às diferenças entre a concepção de cidade de Camilo Sitte e Le Corbusier:

“O fragmentarismo da urbanística sitteana tem uma representação da cidade enquanto um espaço heterogêneo, diferenciado menos pelas funções que abriga - como preconiza a idéia de zoning, formulada por Baumeister e incorporada até as últimas conseqüências por Le Corbusier - e mais pela sua qualidade plástica e pela definição de lugares particulares, com "vida própria" ... Sitte, embora diferenciando o espaço urbano, defende os espaços públicos abertos, utilizados pelos trabalhadores em dias de festa, e critica firmemente o esvaziamento a que o urbanismo moderno os estava submetendo. Como já analisamos anteriormente, ao associar a arquitetura do bloco isolado com o confinamento espacial, Sitte revela-se muito menos conservador do que uma leitura rápida de sua visão hierarquizante da cidade poderia suspeitar, ..."

Nesse sentido, no final da década de 70 , vários projetos urbanos europeus retomaram a tipologia da quadra tradicional européia - a quadrabloco - com edifícios

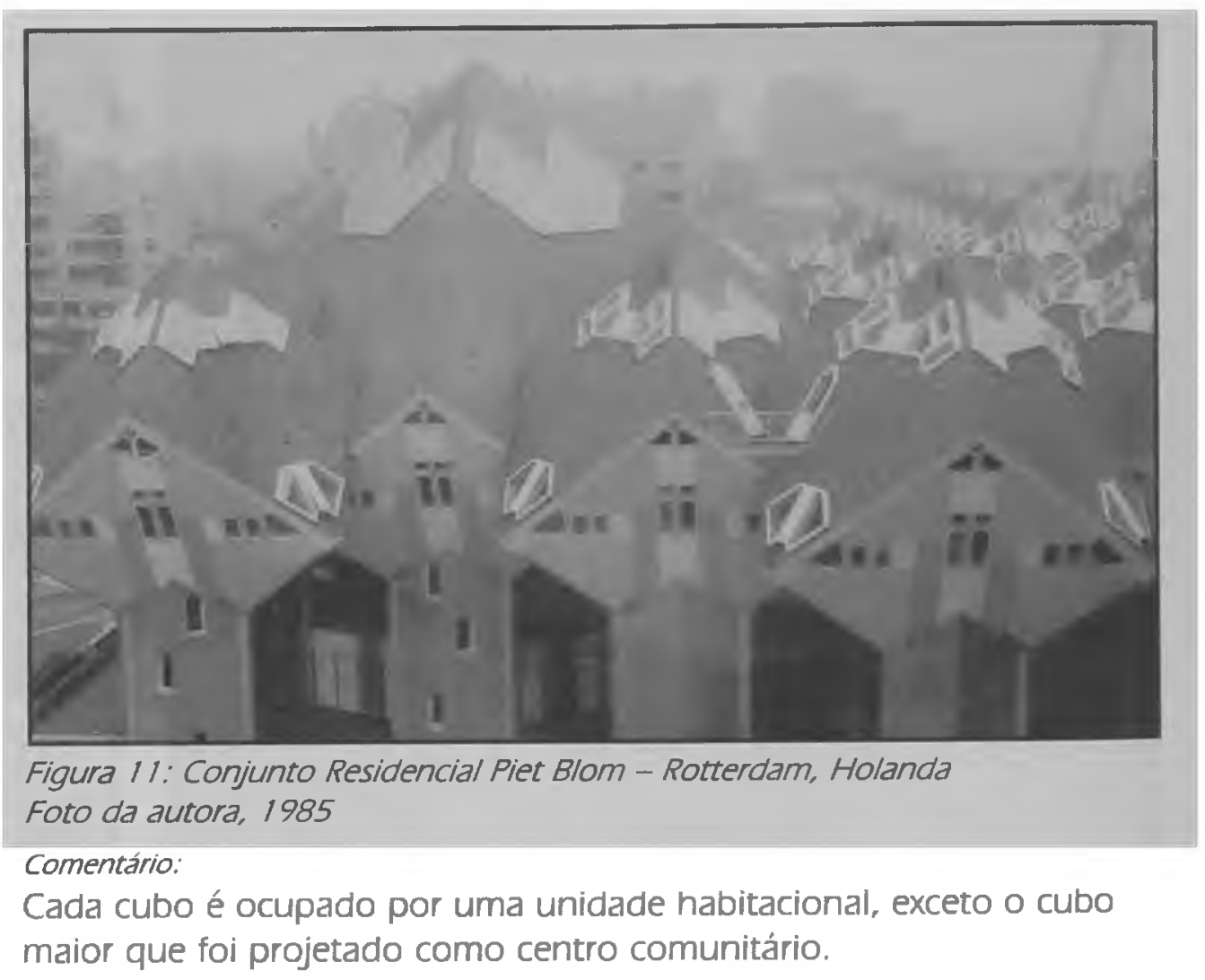

(6) SITTE, Camilo. Construccion de ciudades segun princípios artísticos y el nascimiento del urbanismo moderno. Barcelona: Editorial Gustavo Gili, 1985.

(7) ANDRADE, Carlos Alberto Monteiro de. A peste e o plano. O urbanismo sanitarista do engenheiro Saturnino Brito. Dissertação de Mestrado/FAUUSP, 1992, p. 55 e 69. 
sem recuo, formando pátios internos no interior da quadra. Um dos importantes foros de discussão desse tema foi a "Internationale Bauausstellung Berlin" - IBA, na Alemanha, durante a década de 80.

Se por um lado a IBA - Berlim objetivava a revitalização dos bairros berlinenses deteriorados, devido a parcial destruição, sofrida durante a Segunda Guerra Mundial; por outro promoveu inúmeras reflexões acerca do desenho urbano. Esse debate foi possível em função do número e escala das intervenções previstas, da quantidade de profissionais envolvidos e do caráter internacional da exposição.

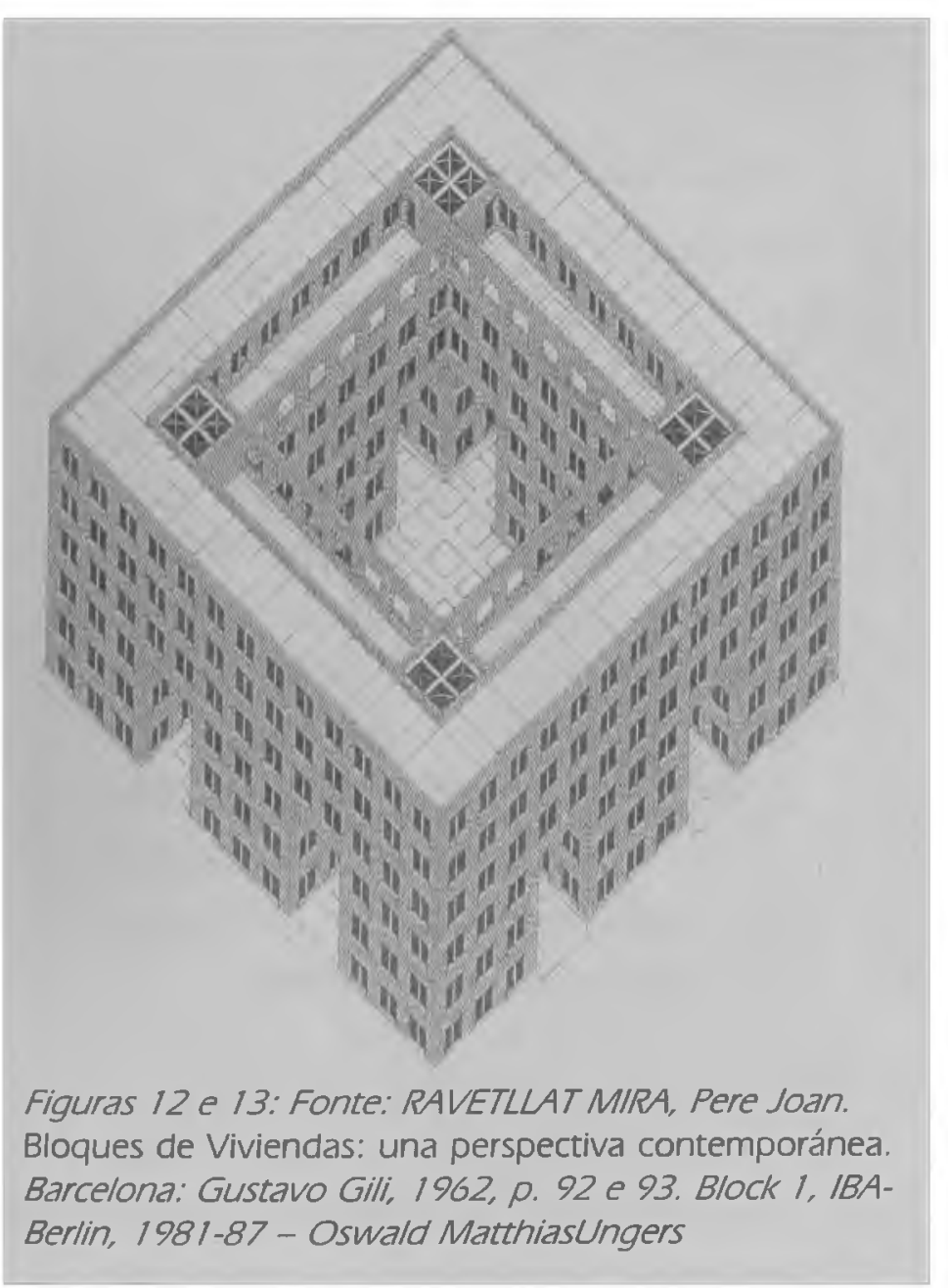

Comentário:

A forma de implantação do conjunto de edifícios ocupa o limite da quadra, situando-se no alinhamento da rua e apresentando pátio central.

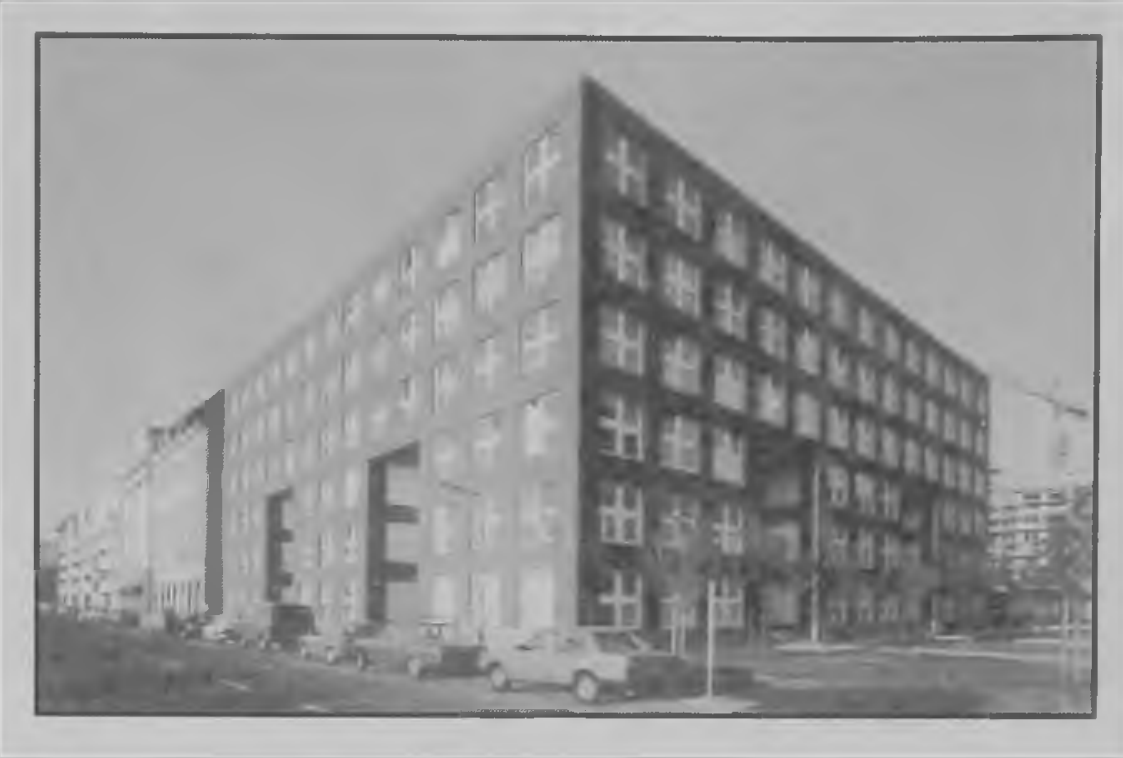

Como resultado, a maior parte dos projetos adotaram a tipologia da "quadra-bloco" recuperando as tradições urbanísticas européias (Figuras 12 e 13).

Os espaços livres, resultantes do desenho da cidade moderna (Figuras 14 e 15), também vão ser revisados. Os arquitetos passam a ter grande preocupação em definir melhor os espaços livres (Figura 16). Foi repensada a relação entre áreas públicas e privadas, incorporam-se os conceitos de áreas livres semipúblicas e semiprivadas, que decorrem do projeto de pequenas áreas e pátios, facilmente apropriáveis para algumas famílias, propiciando maior intimidade (Figuras 17 a 20 ). 

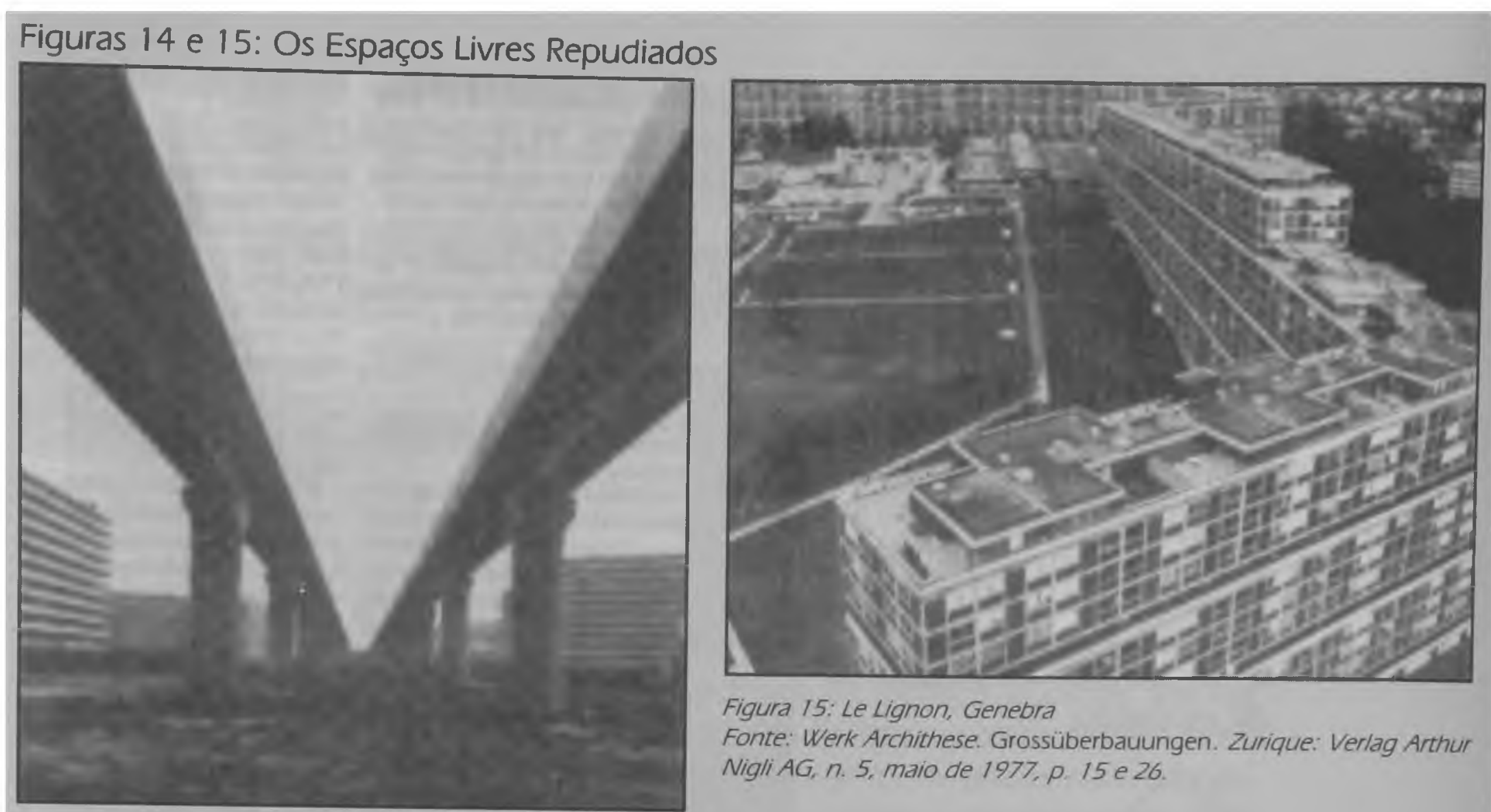

Figura 15: Le Lignon, Genebra

Fonte: Werk Archithese. Grossüberbauungen. Zurique: Verlag Arthur Nigli AG, n. 5, maio de 1977, p. 15 e 26

Figura 14: Biljmemeer, Amsterdam

Comentário:

As figuras mostram os superblocos e os espaços livres esvaziados ("terra de ninguém").

\section{Figuras 16 a 20: Projetando os Espaços Livres}

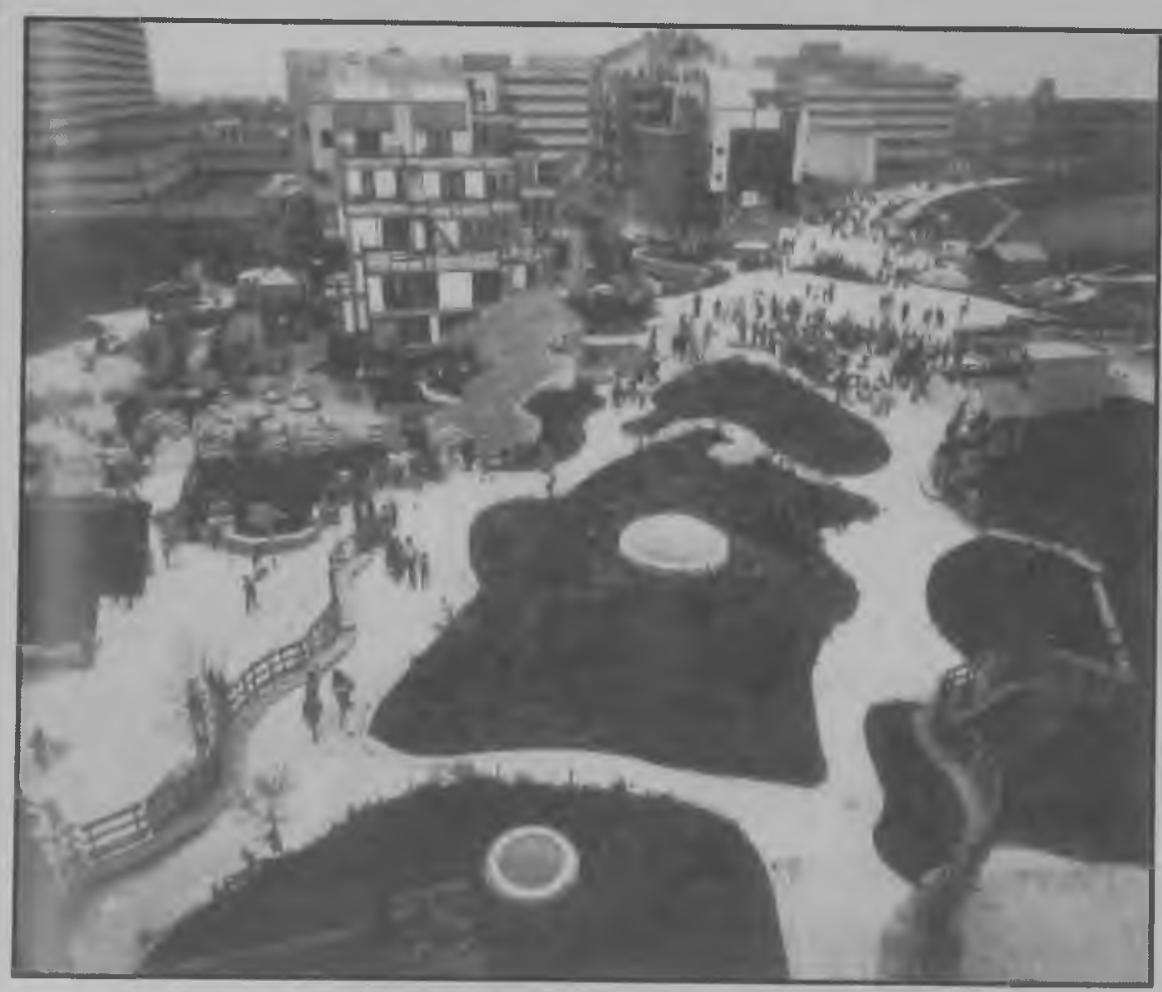

Figura 16: Wolumé-Saint Lambert - Bélgica

Fonte: KROLL, Lucien. Buildings and Projects. Nova York: Rizzoli, 1987, 0. 69.
Além do exemplo acima, várias outras propostas dos anos 80 apresentam importantes elementos de discussão em relação ao projeto do espaço livre, onde se verifica a preocupação em criar diferentes subespaços na área livre interna à quadra. Buscam, também, a diversidade no tratamento das fachadas enriquecendo a paisagem.

Nas fotos 19 e 20 , verifica-se a hierarquização dos espaços livres do interior da quadra, propiciando integração entre os diferentes subespaços, sejam eles privados, semiprivados ou semipúblicos. 
Figuras 17 a 20: Hierarquizando os Espaços Livres

Figuras 17 e 18:

Bailer, Iba - Berlin Fotos da autora, 1985
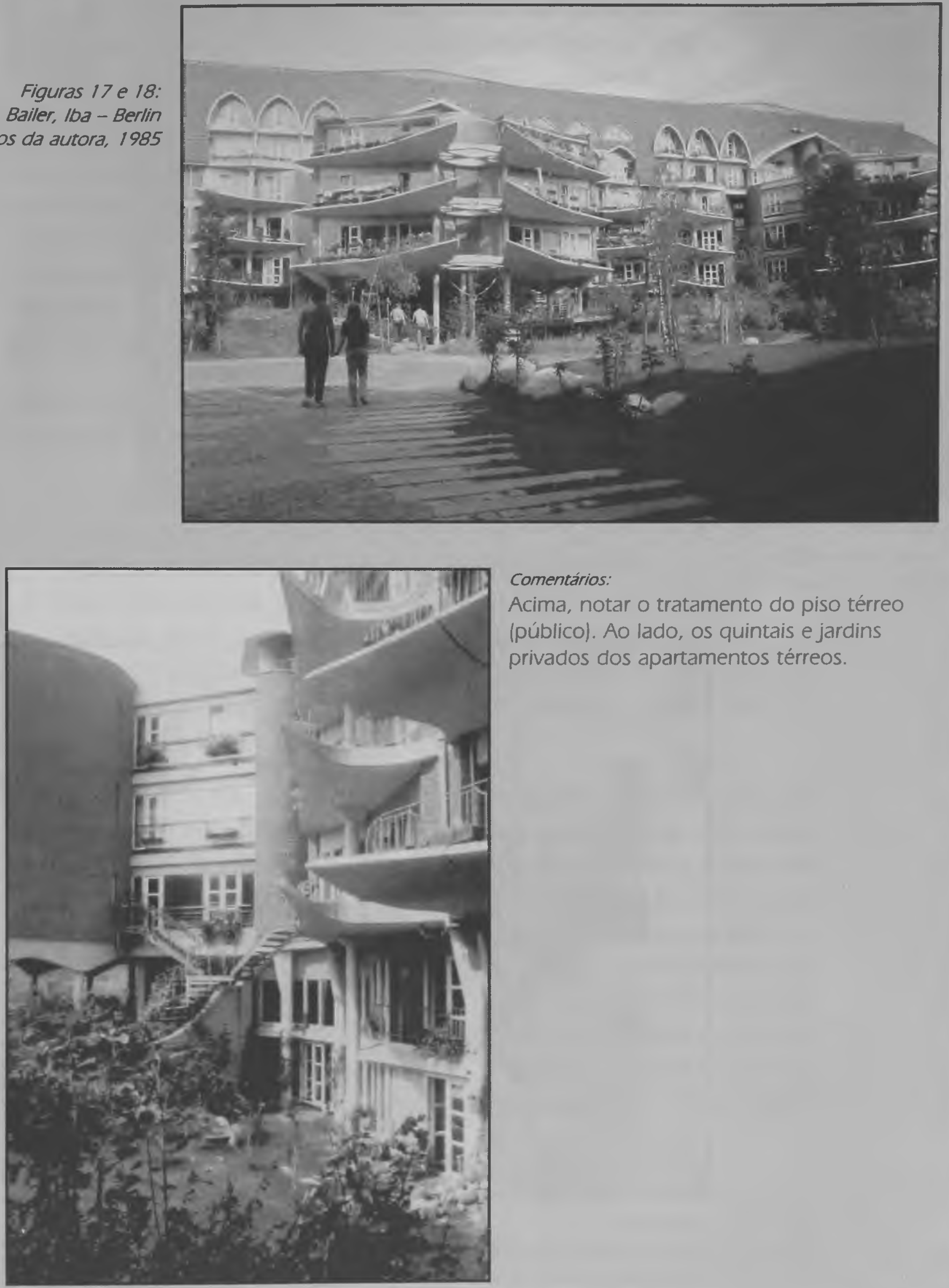

Comentários:

Acima, notar o tratamento do piso térreo (público). Ao lado, os quintais e jardins privados dos apartamentos térreos. 
Marcia

Halluli

Meñnè
Uma Revisão no Desenho dos

Espaços Livres Urbanos dos

Conjuntos Residenciais do

"Urbanismo Moderno"

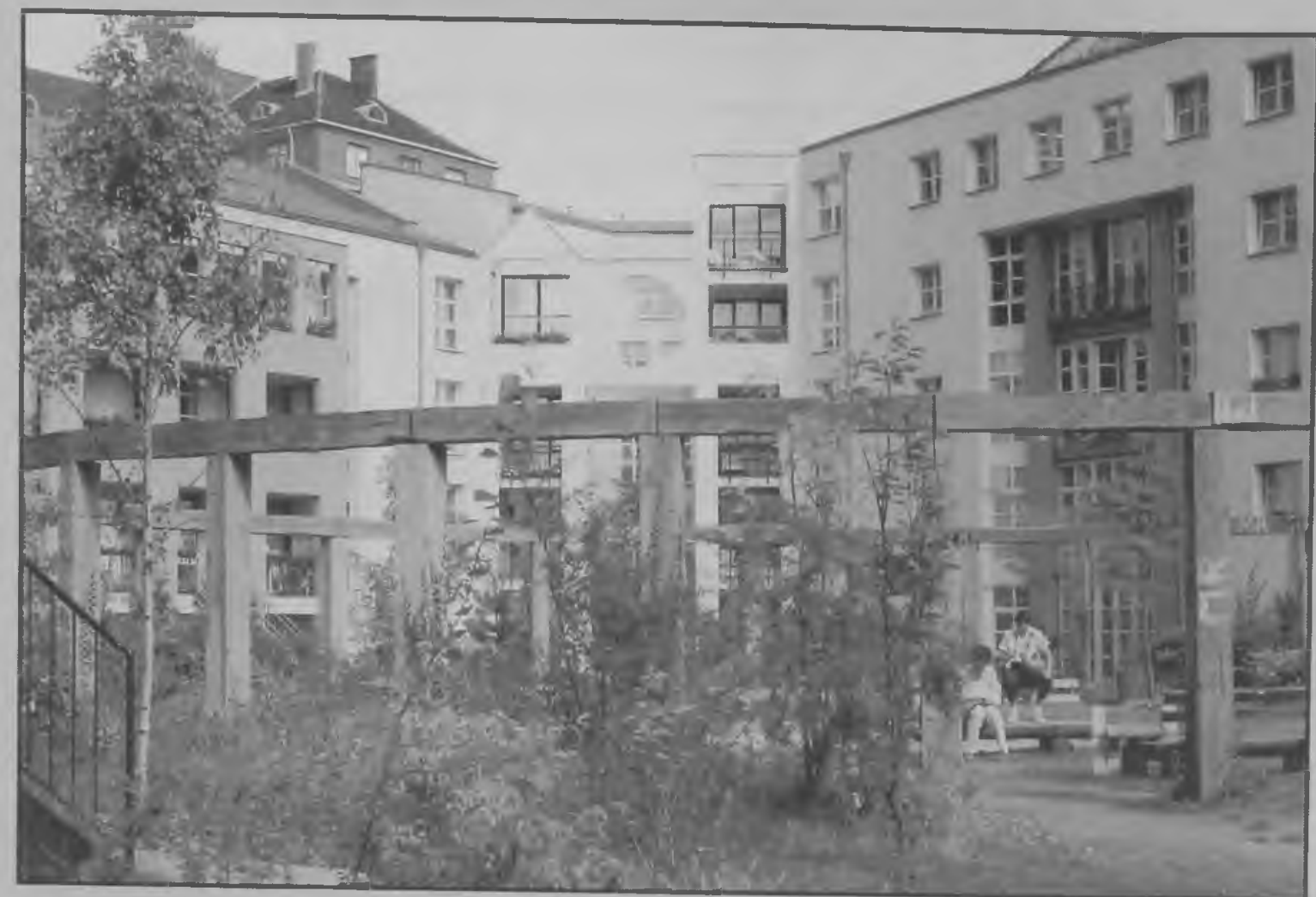

Figuras 19 e 20:

Krier, Iba - Berlin

Fotos da autora, 1985

Comentario:

As figuras mostram os espaços internos à quadra, onde se percebe uma pracinha

coletiva no espaço semiprivado.

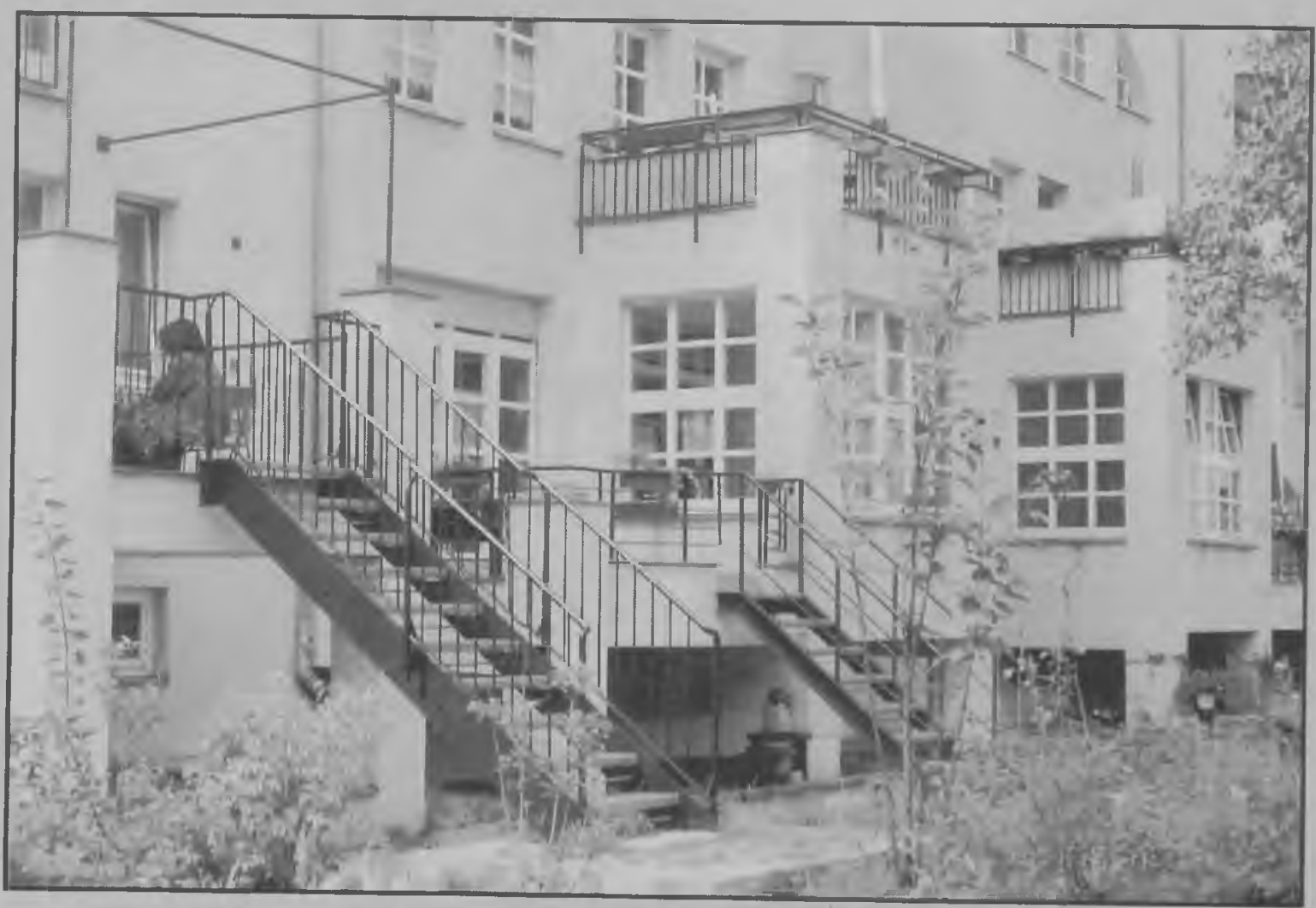

Comentário:

Nota-se uma nova relação do espaço público com o privado /terraças privadas com escadinhas de acesso a partir da área coletiva).

São Paulo n. 11 p. $41 \quad 70 \quad$ dez. 1998 


\section{4 adaptação do modelo habitacional proposto pelo movimento moderno ao projeto dos conjuntos residenciais brasileiros}

No Brasil, a maior parte dos grandes conjuntos habitacionais decorrem de intervençōes financiadas pelo poder público, e estas são numericamente pouco significativas, uma vez comparadas ao déficit habitacional brasileiro. Mesmo assim, a crítica ao urbanismo moderno se estabeleceu enfatizando, a priori, os conjuntos habitacionais populares financiados pelo $\mathrm{BNH}$, que aplicaram o receituário do movimento moderno de forma bastante distorcida (Figura 21).

Alguns dos conceitos atingidos por esta crítica foram bem sintetizados na análise de Comas, quando se refere aos conjuntos habitacionais do BNH:

“... conjunto de blocos repetitivos de apartamentos ......, os blocos identificam-se numericamente; suas portas de ingresso não guardam nenhuma relação consistente com as ruas internas ou periféricas do conjunto. ... Os espaços abertos entre as edificações não ocupados por ruas ou estacionamentos descobertos são sempre coletivos e nunca compartimentados, permitindo livre acesso a todos os moradores e à vizinhança."8

Aponta, ainda, a dificuldade de apropriação dos espaços abertos (que ele chama de "terra de ninguém") e de orientação parcial ou global, dentro do conjunto, devido à padronização dos blocos e à falta de identidade de suas entradas, ruas e caminhos. Assim sendo, coloca que os princípios modernistas ao propor uma menor ocupação do solo e o afastamento das divisas do lote, faz com que a cidade tenda a se transformar "numa coleção de intervenções singulares aleatoriamente justapostas" onde se percebem regras rígidas para o projeto do espaço construído privado e excessiva liberdade ao projeto do espaço público. Essa descrição genérica explica o projeto do Conjunto Habitacional Carapicuíba (Figuras 21 e 22).

(8) COMAS, Carlos Eduardo Dias. O espaço da arbitrariedade. Considerações sobre o conjunto habitacional BNH e o projeto da cidade brasileira. Revista Projeto, n. 91, set. de 1986, São Paulo, p. 127.

\begin{tabular}{|l|l|l|}
\cline { 1 - 2 } & São Paulo n. 11 p. $41 \quad 70$ dez. 1998 & $\begin{array}{l}\text { Paisagem } \\
\text { Amblente } \\
\text { Ensalos } \\
11\end{array}$ \\
\hline
\end{tabular}




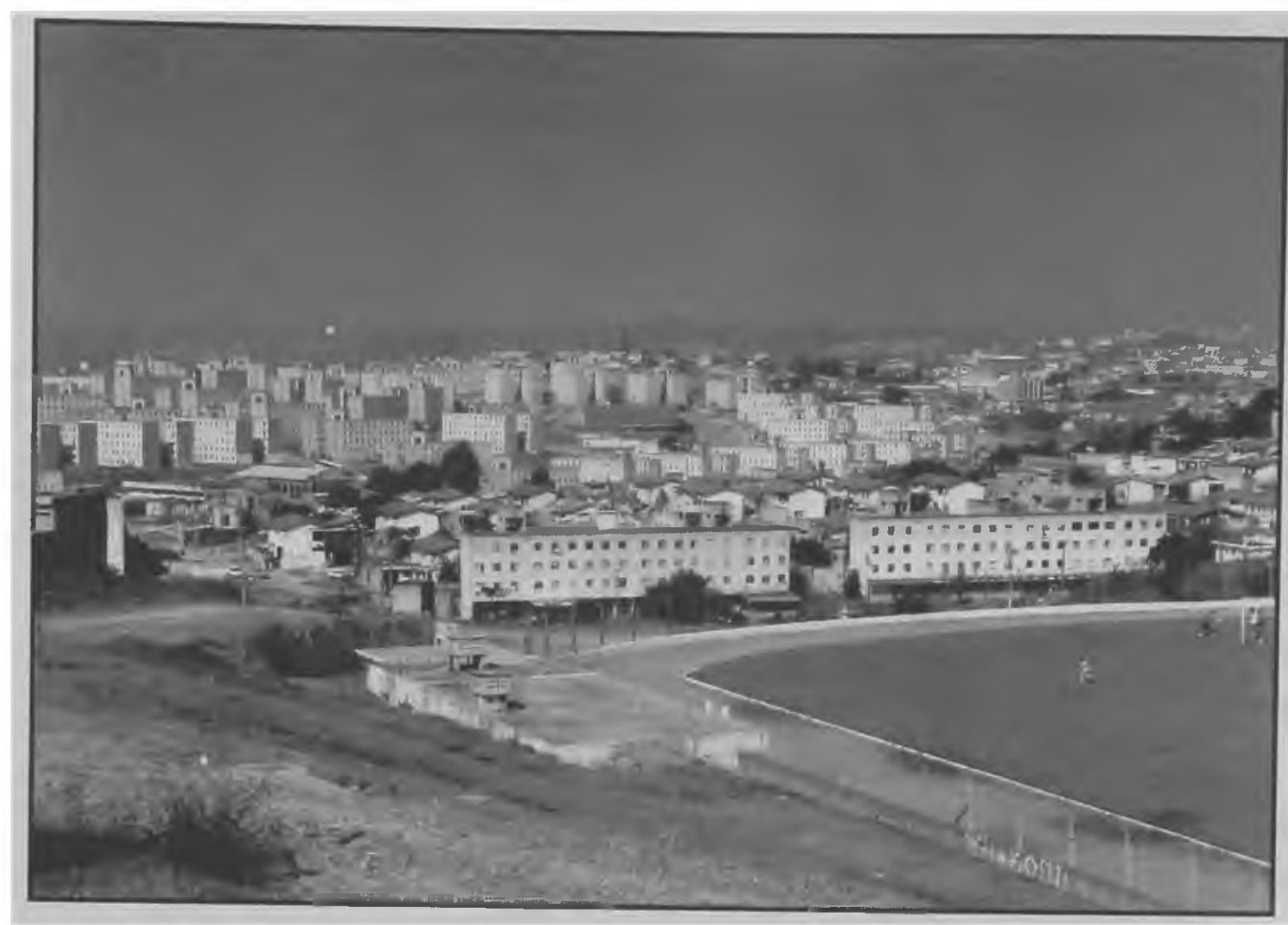

Figura 21: Conjunto Habitacional CohabCarapicuíba Foto da autora

Figura 22: Cohab-Carapicuíba Fonte: Mapa adaptado de AGGIO, Sandra Mara. O urbanismo no Brasil e a crise da modernidade, Dissertação de Mestrado/ PUC-SP, São Paulo, 1993, Capitulo 4.

"Conjuntos habitacionais no Brasil: $A$ legitimação regressiva do repertório urbanistico modernista".

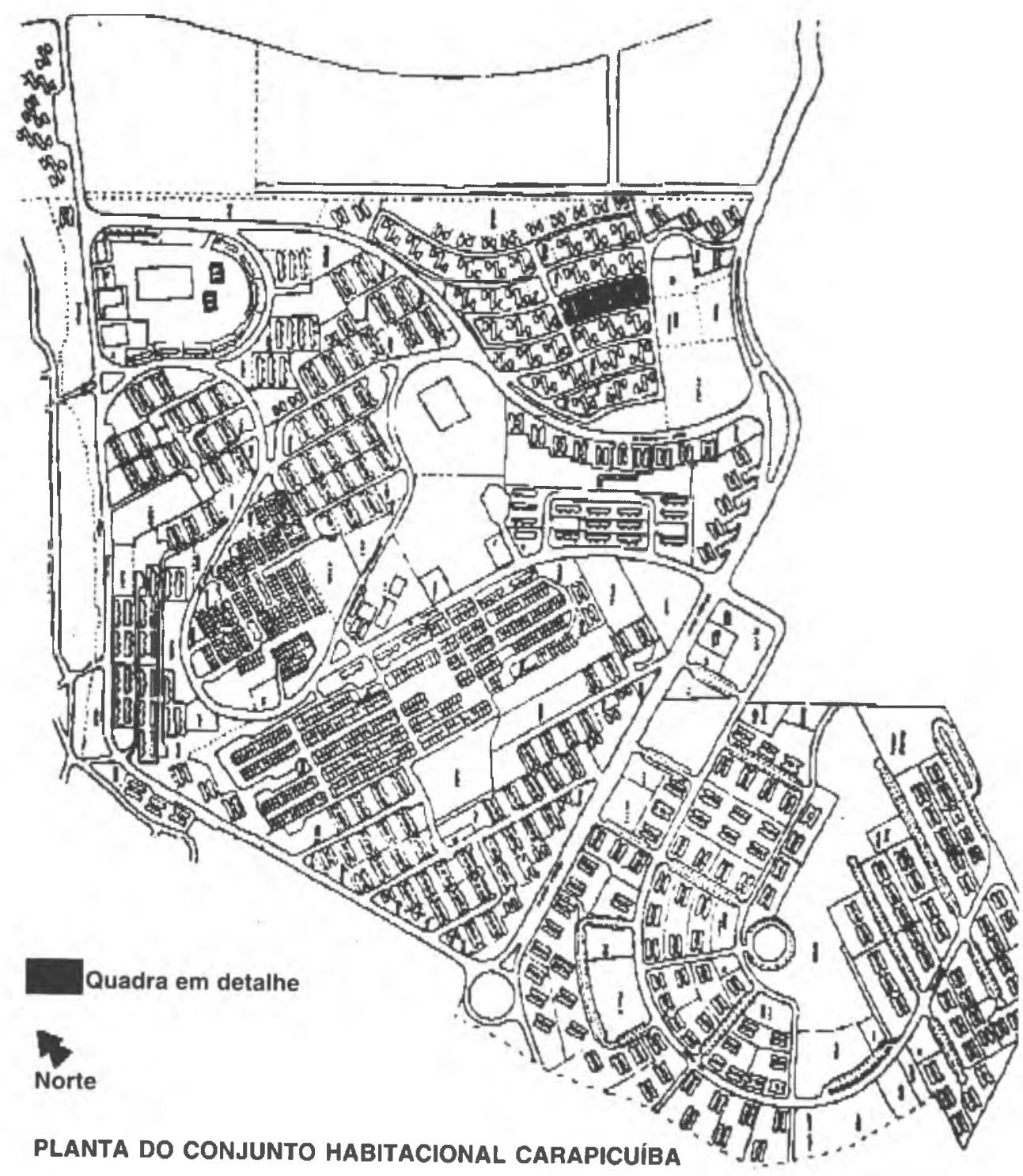

\begin{tabular}{|l|l|}
\hline 60 & $\begin{array}{l}\text { Paisagem } \\
\text { Ambiente } \\
\text { Ensaios } \\
11\end{array}$ \\
\hline
\end{tabular}

São Paulo n. 11 p. 41 - 70 - dez. 1998 
O conjunto é formado por edifícios padronizados - blocos isolados em forma de um " $H$ " ou em forma de lâmina (no caso metade do edifício "H") - onde as variações tipológicas constatadas resultam das possibilidades de agrupamento de dois edifícios " $\mathrm{H}$ "

Como a maior parte do conjuntos habitacionais do BNH, apresenta-se como uma "ilha urbana" uma vez que não se verifica a integração da malha urbana do conjunto com o entorno. Observa-se que esses conjuntos foram construídos ao mesmo tempo em que se deu a abertura de novos loteamentos populares (quase sempre clandestinos). Como, na periferia de São Paulo e cidades vizinhas, foram produzidos mais loteamentos populares que conjuntos habitacionais do $\mathrm{BNH}$, configura-se uma paisagem homogênea e repetitiva, com pontos de descontinuidade nos locais onde os mesmos foram construídos. Estes, por sua vez, destacam-se pela sua forma de ordenação e pela monotonia da paisagem resultante.

Uma das principais distorções em relação ao modelo proposto pela Carta de Atenas refere-se ao sistema de circulação. No caso de Carapicuíba, não se identifica uma hierarquia viária clara e no lugar de "vias" e "caminhos" encontram-se ruas, que em função de suas dimensōes /calçadas beirando os $80 \mathrm{~cm}$ e leito carroçável com aproximadamente $6 \mathrm{~m}$ ), não respeitam nem a escala do pedestre, nem a do veículo.

Para a apropriação dos espaços livres, constata-se que os moradores do conjunto sentiram a necessidade de alterar as características morfológicas, impostas pelo projeto, transformando as relaçōes entre espaço livre e espaço construído. Para exemplificar a natureza das alterações sofridas pelos espaços livres do conjunto, apresenta-se um levantamento, realizado in loco, de uma de suas quadras 9 (Figura 23).

(9) Esse levantamento foi realizado em 1991, para elaboraçāo de trabalho da autora, referente a disciplina AUP-810, ministrada pelo Prof. Dr. Silvio Soares Macedo. Do mesmo texto, foi transcrita parte das análises referentes ao Conjunto Habitacional de Carapicuiba.

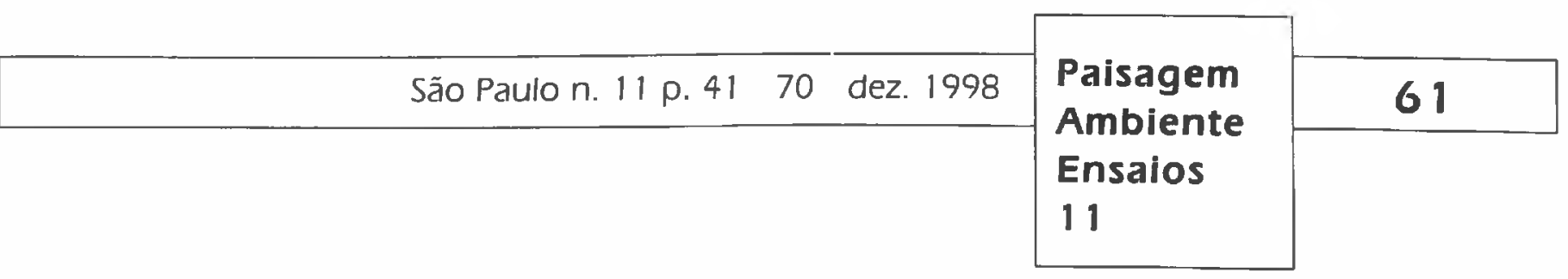


Figura 23

Levantamento de uma quadra tipica do conjunto Fonte: Levantamento realizado in loco pela autora

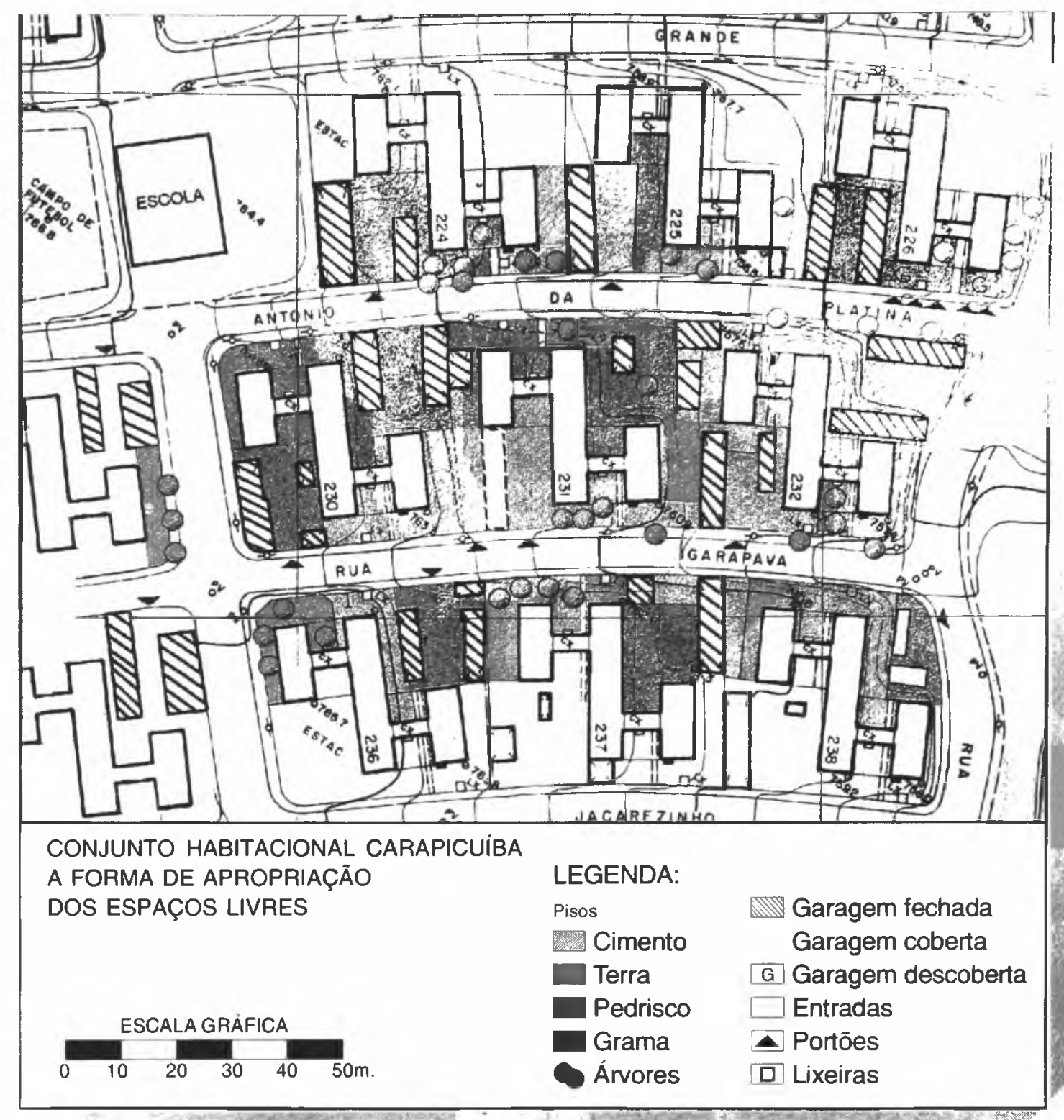

Verifica-se a completa alteração dos espaços livres públicos e privados do conjunto. As intervenções dos moradores objetivaram personalizar os espaços contíguos a seus edifícios e definir o "indefinido" Elas consistem em edificar, recortar e dividir os espaços livres, sem projeto, nem orientação de profissionais qualificados (Figuras 24 a 28).

À primeira vista, esse tipo de apropriação desordenada é indesejável, particularmente pelos problemas que pode ocasionar: o corte de taludes de contenção; a total impermeabilização do solo das áreas semiprivadas; o prejuízo da ventilação e insolação dos apartamentos térreos; a construção ilegal de garagens cobertas e, finalmente, a redução e descontinuidade das áreas de lazer coletivo.

\begin{tabular}{|c|c|c|}
\hline 62 & Paisagem & São Paulo n. 11 p. $41 \quad 70$ - dez. 1998 \\
\hline & $\begin{array}{l}\text { Ensaios } \\
11\end{array}$ & \\
\hline
\end{tabular}


Porém, após a percepção da nova ordem estabelecida, verifica-se o seguinte:

1) Os pequenos estabelecimentos comerciais e de serviços, que ocupam algumas "garagens" são necessários ao atendimento da demanda local. Mais uma vez, a população altera a proposta do projeto, onde o zoneamento de usos era mais rígido, concentrando as áreas comerciais em lotes de $2.000 \mathrm{~m}^{2}$ Os estabelecimentos comerciais, necessários a suprir a demanda de comércio e serviços do bairro, poucas vezes exigem áreas desse porte. Nas quadras estudadas, o terreno onde hoje localiza-se a escola era inicialmente destinado ao comércio.

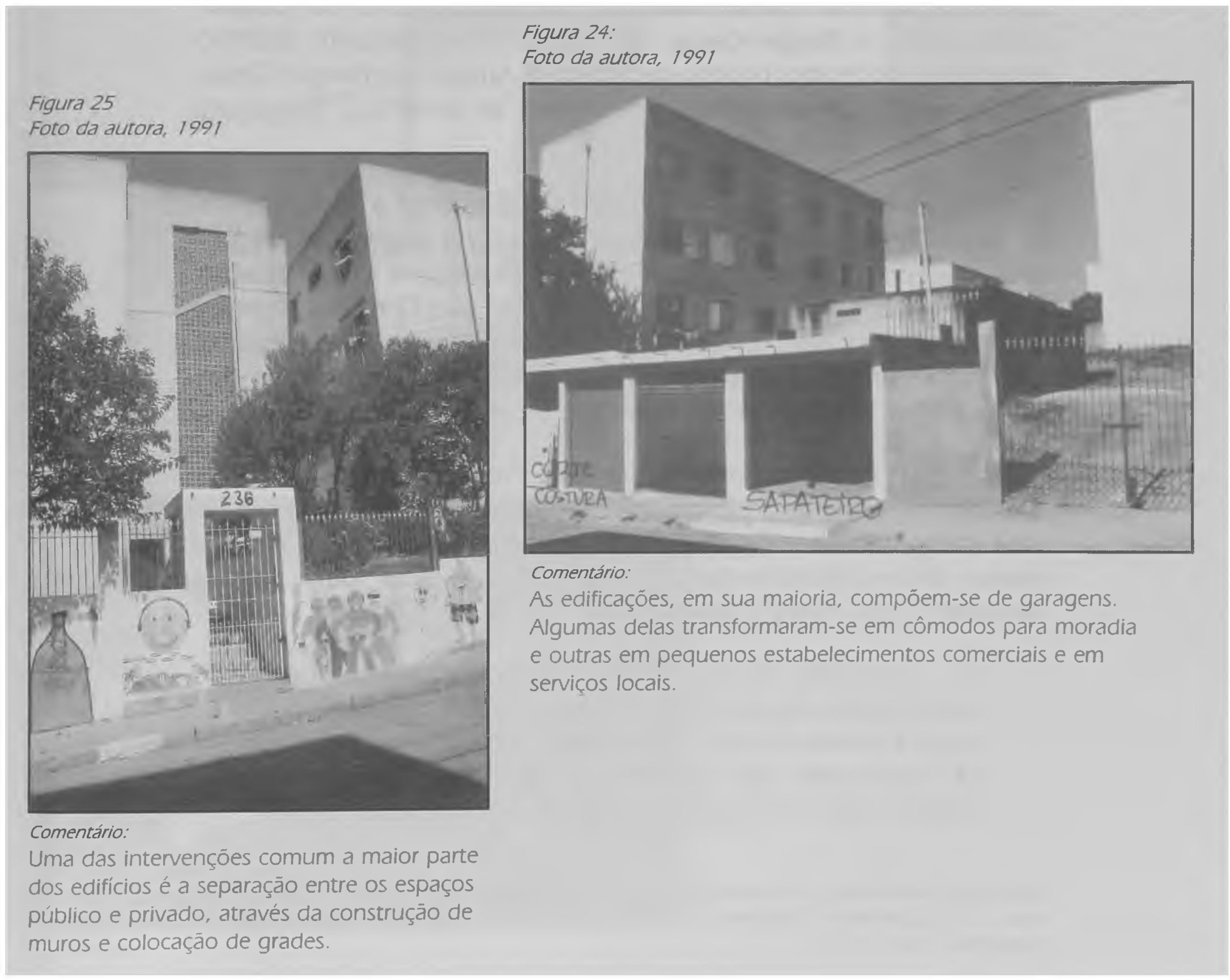


2) Apesar de recortados e pequenos, os espaços livres privados são mais definidos. O lazer infantil ocorre nas ruas estreitas ou nos pequenos pátios, formados pelos desniveis, que oferecem apenas um piso cimentado. Qualquer degrau ou saliência, vira um ponto de encontro (Figura 26 a 29).

Com as alteraçōes, os moradores vão reproduzindo, pouco a pouco, os padrões urbanísticos conhecidos: muros de fechamento do lote, garagens cobertas e pequenos estabelecimentos comerciais. Com isso, a rua do conjunto vai tomando a configuração da rua do tecido urbano tradicional (Figura 28).

Aggio ${ }^{10}$, ao discutir os conjuntos habitacionais do $\mathrm{BNH}$, fez uma comparação entre três propostas diferenciadas: a da CohabCarapicuíba, o Parque Cecap de Guarulhos - Conjunto Zézinho Magalhães do Prado, projeto de Vilanova Artigas e o Parque Cecap de Taubaté - Conjunto Quiririm, projeto de Bonilha e Sancovsky (Figura 29).

Enquanto no projeto de Carapicuíba constatou-se a distorção do modelo proposto pelo movimento moderno; no projeto de Artigas, apesar de não ter sido totalmente executado, verifica-se a real aplicação dos conceitos propostos pela Carta de Atenas. Já o Conjunto Quiririm é composto por um conjunto de vilas, organizadas num desenho ortogonal. Através destes três exemplos, Aggio ressalta a forma dos espaços livres públicos, resultantes de cada proposta.

Pelos croquis apresentados, observa-se que ao contrário do Conjunto Carapicuíba, onde as áreas públicas sāo distribuídas sem critério; há uma intencionalidade na distribuição e forma dos espaços livres dos outros dois conjuntos, com o intuito de propiciar uma melhor apropriação dos espaços livres resultantes.

“Se o Conjunto Carapicuíba é uma versão caricatural das teses contidas no repertório modernista, o Conjunto Parque Cecap Quiririn, também racionalista, propõe uma alteração na organização das unidades de vizinhança. Os espaços públicos são concebidos não mais para toda a coletividade

(10) AGGIO, Sandra Mara. O urbanismo no Brasil e a crise da modernidade. Dissertação de Mestrado/PUC-SP, São Paulo, 1993, Capítulo 4: “Conjuntos habitacionais no Brasil: A legitimação regressiva do repertório urbanístico modernista" p. 79 a 115. 
Figuras 26 e 27 - Conjunto Habitacional de Carapicuíba

Uma Revisão no Desenho dos

Espaços Livres Urbanos dos

Conjuntos Residenciais do "Urbanismo Moderno"

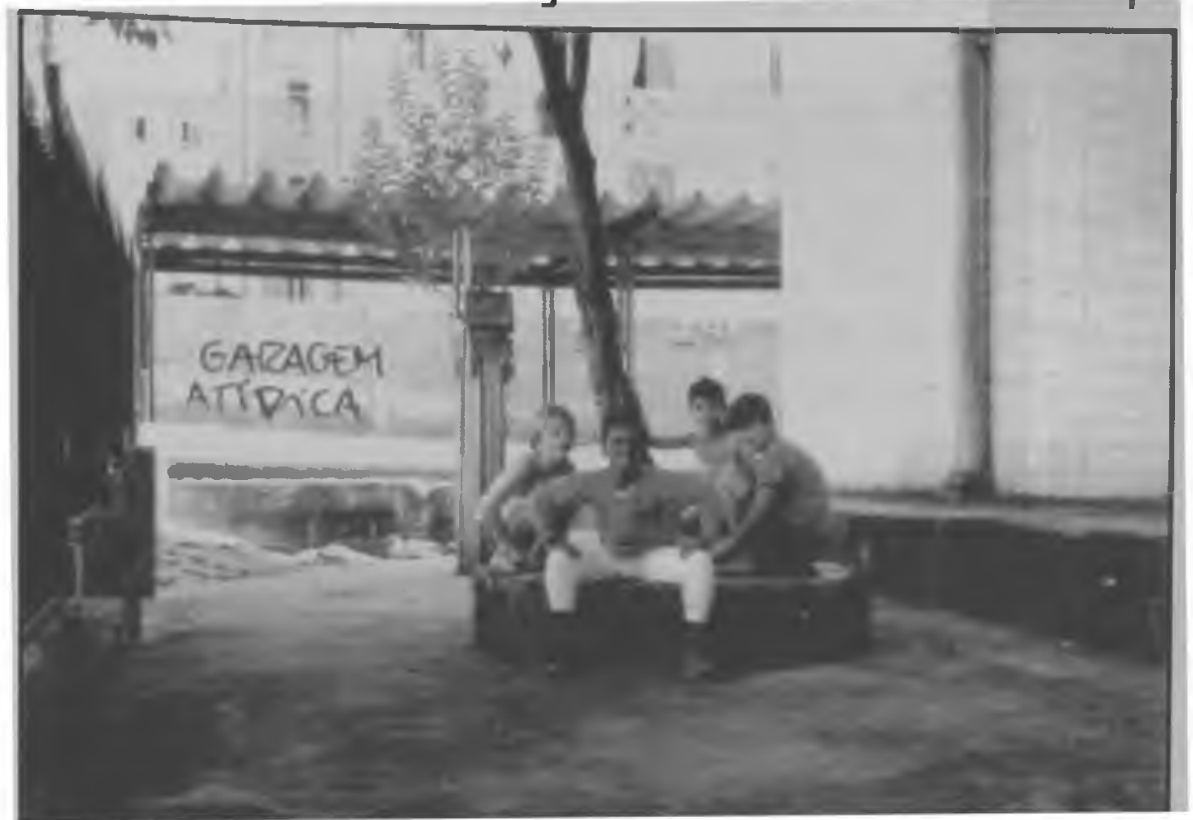

Figura 26

Foto da autora, 1991
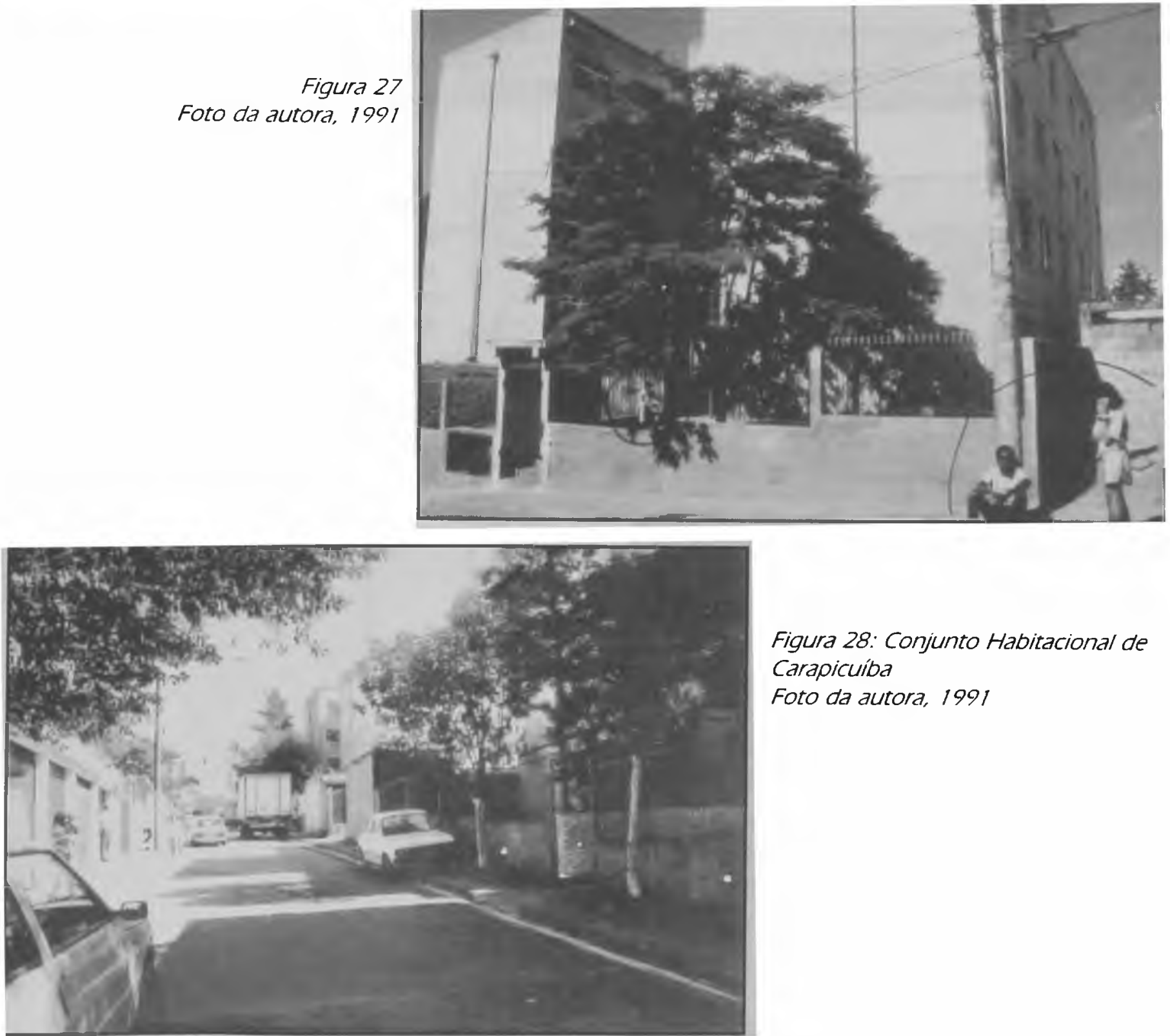

Figura 28: Conjunto Habitacional de Carapicuiba

Foto da autora, 1991

Comentário

As figuras mostram os pontos de encontro e de descanso informais 

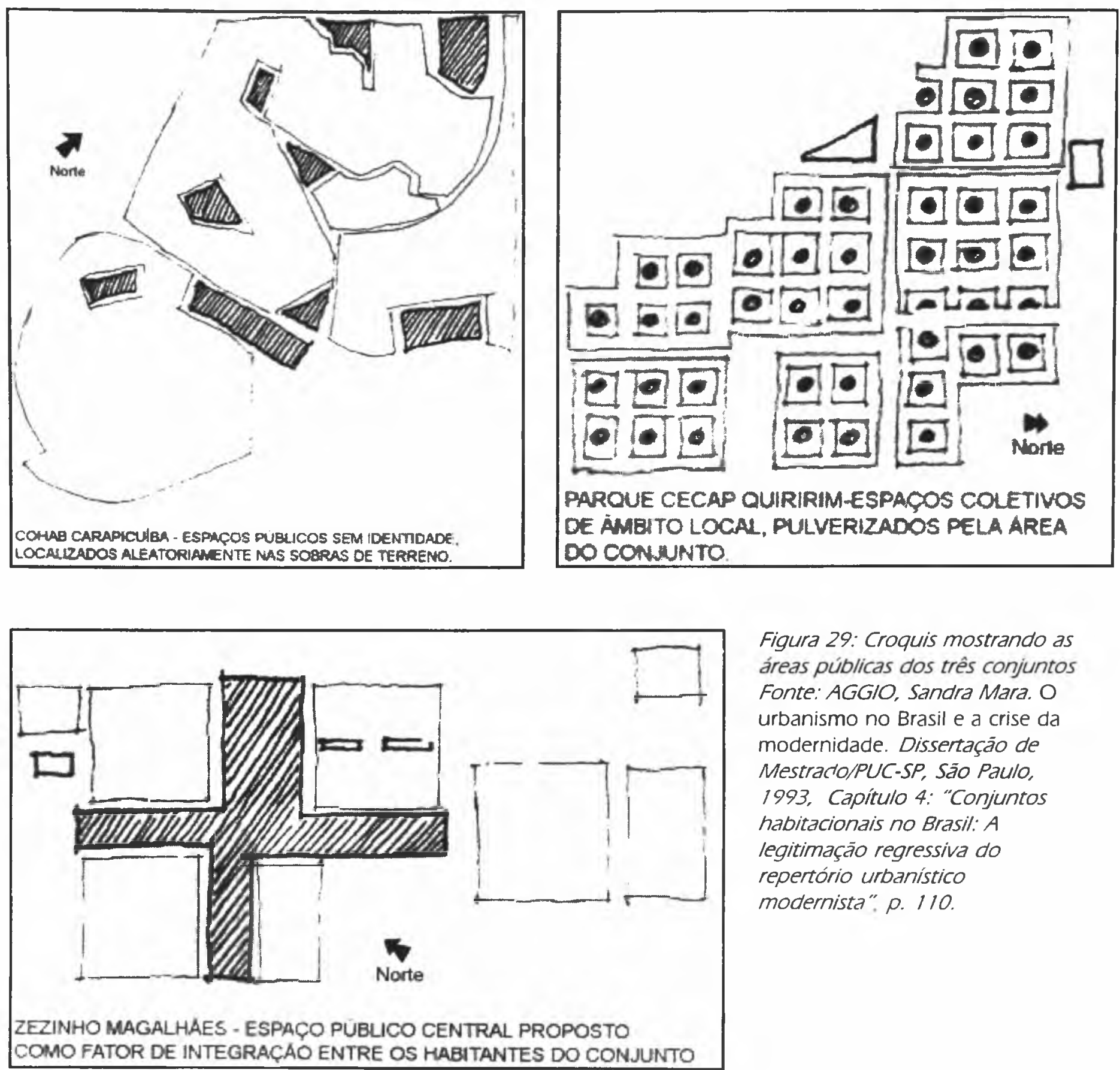

Figura 29: Croquis mostrando as áreas públicas dos três conjuntos Fonte: AGGIO, Sandra Mara. O urbanismo no Brasil e a crise da modernidade. Dissertação de MestractolPUC-SP, São PaUlo, 1993. Capítulo 4: "Conjuntos habitacionais no Brasil: $A$ legitimação regressiva do repertório urbanístico modernista". p. 110.

do conjunto, mas para cada vila em particular, objetivando com isso estimular uma interação entre os moradores num nivel mais local." 11

O Conjunto Zezinho Magalhães do Prado, em seu projeto original, oferece $100 \%$ de espaços públicos, mas sem nenhuma hierarquização.

(11) AGGIO, Sandra Mara. O urbanismo no Brasil e a crise da modernidade. Dissertação de Mestrado/PUC-SP, São Paulo, 1993, Capítulo 4: "Conjuntos habitacionais no Brasil: A legitimação regressiva do repertório urbanístico modernista" p. 86.

\begin{tabular}{|l|l|}
\hline 66 & Paisagem \\
Ambiente \\
Ensaios \\
11
\end{tabular}

São Paulo n. 11 p. 4170 - dez. 1998 
No âmbito dos conjuntos residenciais populares, algumas experiências mais recentes vêm de encontro às críticas formuladas aos conjuntos habitacionais do $\mathrm{BNH}$, buscando alterar o quadro descrito, como é o caso das experiências desenvolvidas por mutirão na cidade de São Paulo, durante a gestão da prefeita Luíza Erundina (Figura 30). Estas propostas são alternativas ao modelo habitacional utilizado pela Cohab, a começar pelo porte dos conjuntos, onde se verifica o limite aproximado de 200 famílias por conjunto.

Um exemplo significativo, apesar de inacabado, é a proposta para o Conjunto Residencial São Francisco - Setor 8, em São Mateus que foi objeto de concurso público, promovido pela prefeitura do Município de São Paulo, para construção de habitação popular (Figura 30). O projeto do conjunto é composto por unidades habitacionais sobrepostas, apresentando diversidade de paisagem e hierarquização dos espaços livres.

Figura 30: Coninto Habitacional São Francisco 8 Fonte: Revista Projeto. Suplemento Especial: Da utopia à construção: $A$ participação popular na política habitacional em São Paulo. São Paulo, 1992, ค. SPI3.

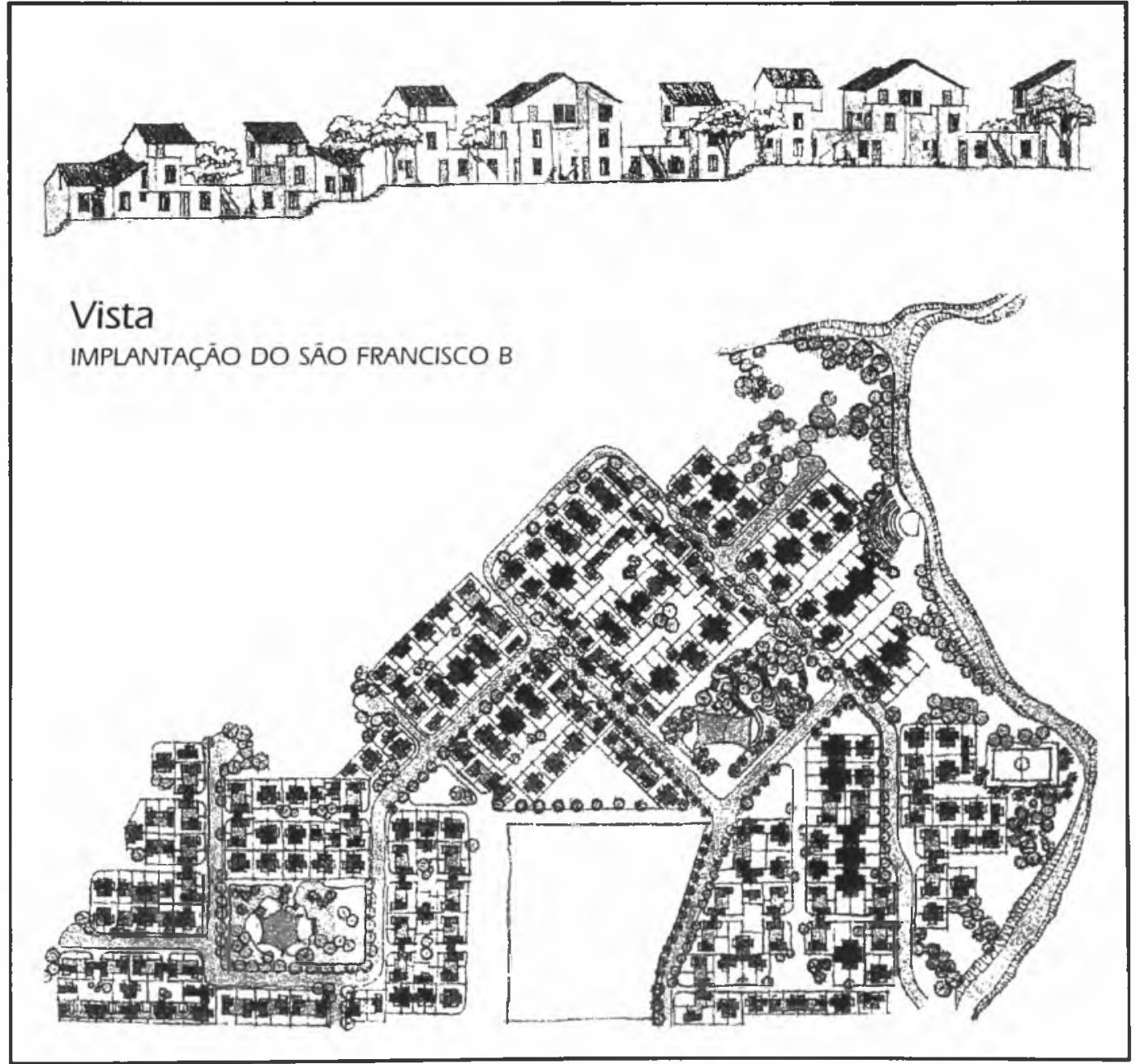

São Paulo n. 11 p. 4170 dez. 1998

\section{Paisagem Ambiente Ensaios 11}


A proposta inicial era integrar as diferentes quadras através da circulação de pedestres e liberar áreas livres coletivas no meio delas. Como o conjunto ficou inacabado, esses espaços estão sendo, pouco a pouco, complementados e apropriados pelos moradores, que repetem os padrões urbanos conhecidos. Identifica-se este processo na tentativa de tentar cercar os lotes e construir garagens cobertas.

Apesar da dificuldade de implantação de novas propostas, especialmente das que apresentam uma maior dificuldade construtiva, percebe-se já uma maior compreensão por parte de alguns políticos brasileiros acerca da necessidade de rever o desenho dos conjuntos habitacionais para as camadas de renda mais baixa. Outros exemplos, inclusive duas propostas utilizando esta mesma tipologia (elaboradas pelo mesmo grupo) foram implantados também na cidade do Rio de Janeiro.

Se o desenho da paisagem habitacional já é hoje uma preocupação de cunho político, a necessidade de equipar as áreas públicas destes conjuntos residenciais adequadamente ainda não figura entre as prioridades da maior parte dos políticos. Estas, quando existem são espaços sem atrativo nenhum e em péssimo estado de conservação. Porém, espera-se que, num prazo relativamente curto, estas começarão a ser redesenhadas, uma vez que as áreas públicas de maior impacto no conjunto da cidade já têm sido objeto de inúmeros projetos de renovação urbana em várias cidades brasileiras.

\section{B】BLIOG RAFIA}

AGGIO, Sandra Mara. O urbanismo no Brasil e a crise da modernidade. São Paulo, 1993. Dissertação (Mestrado) PUC-SP. Capítulo 4: Conjuntos habitacionais no Brasil: A legitimação regressiva do repertório urbanístico modernista, p. 79 a 115.

ANDRADE, Carlos Alberto Monteiro de. A peste e o plano. O urbanismo sanitarista do engenheiro Saturnino Brito. São Paulo, 1992. Dissertação (Mestrado) - Faculdade de Arquitetura e Urbanismo, Universidade de São Paulo.

AYMONINO, Carlo. El significado de las ciudades. Madri: $\mathrm{H}$. Blume Ediciones.

BAKER, Geoffrey H. Analisis de la forma; urbanismo y arquitectura. Barcelona: Gustavo Gili, 1989.

BENEVOLO, Leonardo. História da cidade. São Paulo: Perspectiva, 1983.

História da arquitetura moderna. São Paulo: Perspectiva, 1976

O último capítulo da arquitetura moderna. Lisboa: Martins Fontes, 1985.

CASTEX; DEPAULE; PANERAI. Formas urbanas: de la manzana al bloque. Barcelona: Gustavo Gili, 1986.

\begin{tabular}{|c|c|c|}
\hline 68 & Paisagem & São Paulo n. 11 p. $41 \quad 70$ dez. 1998 \\
\hline & $\begin{array}{l}\text { Ensaios } \\
11\end{array}$ & \\
\hline
\end{tabular}


COMAs, Carlos Eduardo Dias. O espaço da arbitrariedade. Considerações sobre o conjunto habitacional BNH e o projeto da cidade brasileira. Revista Projeto, $n$. 91 , set. de 1986, Projeto Editores Associados Ltda., São Paulo.

DEL RIO, Vicente. Introdução ao desenho urbano no processo de planejamento. São Paulo: Pini, 1990.

FARRET, KOHLSDORF, HOLANDAVGONZALES. O espaço da cidade. Contribuiçāo à análise urbana. São Paulo: Projeto Editores Associados Ltda., 1985.

FERREIRA, Nadia Somekh. A cidade vertical e o urbanismo modernizador: São Paulo, 1920-1930. São Paulo, 1994. Tese (Doutorado) - Faculdade de Arquitetura e Urbanismo, Universidade de São Paulo.

hOLSTON, James. A cidade modernista. Uma crítica de Brasília e sua utopia. São Paulo: Cia. das Letras, Editora Schwarcz Ltda., 1993.

HUET, Bernard. A cidade como espaço habitável (alternativas à Carta de Atenas). Revista AU, São Paulo, dez./jan. de 86/87.

IBAVDokumente ProjeKte 1. Modelle für eine Stadt. Berlin: Die Neubaugebiete, Siedler Verlag, 1984.

KRIER, Rob. El espacio urbano. Barcelona: Editorial Gustavo Gili, 1981.

KOPP, Anatole. Ouando o moderno não era um estilo e sim uma causa. Sāo Paulo: Nobel/Edusp. 1990.

Modernismo hoje. Tradução e notas de Reginaldo Forti sobre a palestra "Modernisme Aujourd'hui" Revista AU. São Paulo, dez./jan. de 86/87, Pini Editora.

KROLL, Lucien. Buildings and projects. Nova York: Rizzoli, 1987.

LA ANARQUITETURA DE LUCIEN KROLL. In: Collección Summarios, Buenos Aires: n. 33, Edicionnes Summa, jul. de 1979.

LAMAS, José M. Ressano Garcia. Morfologia urbana e desenho da cidade. Lisboa: Fundaçāo Calouste Gulbenkian/Junta Nacional de Investigação Científica e Tecnológica, 1993.

LYNCH, Kevin. A imagem da cidade. São Paulo: Martins Fontes, 1982.

La buena forma de la ciudad. Barcelona: Gustavo Gili, 1985.

Planificación del sítio. Barcelona: Gustavo Gili, 1980.

MACEDO, Silvio Soares. São Paulo, paisagem e habitação verticalizada. Os espaços livres como elementos de desenho urbano. São Paulo, 1988. Tese (Doutorado) - Faculdade de Arquitetura e Urbanismo, Universidade de São Paulo.

Higienópolis e arredores. Processo de mutação da paisagem urbana. São Paulo: Edusp/Pini, 1987.

MAGNOLI, Miranda Martinelli. Espaços livres e urbanização: uma introdução a aspectos da paisagem metropolitana. Sāo Paulo. Tese (Livre-Docência) - Faculdade de Arquitetura e Urbanismo, Universidade de São Paulo.

MEYER, Regina. Metrópole e urbanismo: São Paulo anos 50. São Paulo, 1991. Tese (Doutorado) - Faculdade de Arquitetura e Urbanismo, Universidade de São Paulo.

RAPOPORT, Amos. Aspectos de la forma urbana. Barcelona: Gustavo Gili, 1978.

RAVETLLAT MIRA, Pere Joan. Bloques de viviendas: una perspectiva contemporánea. Barcelona: Gustavo Gili, 1992.

REVISTA AU. Arquitetura e urbanismo. São Paulo: Pini Editora, n. 16, fev./mar. 1988; n. 26, out./ nov. 1989; n. 50, out./nov. 1993. 
Marcia Uma Revisão no Desenho dos

Halluli Espaços Livres Urbanos dos

Menneh Conjuntos Residenciais do

"Urbanismo Moderno"

REVISTA PROJETO. São Paulo: Projeto Editores Associados Ltda., n. 66, ago. 1984; n. 129, jan./ fev. 1990.

ROSSI, Aldo. A arquitetura da cidade. Lisboa: Ed. Cosmos, 1977.

ROWE,C./KOETTER F Ciudad collage. Barcelona: Gustavo Gili, 1978.

SANTOS, Carlos Nelson Ferreira. A cidade como um jogo de cartas. São Paulo/Niterói: Projeto/ Eduff, 1988

SITTE, Camilo. The ant of building cities. Trad. Charles T. Stewart. Nova York: Reinhold, 1945. SMITHSON, ALISON, PETER. Urban structuring. Nova York: Reinhold, 1967.

SOUZA, Maria Adélia. A identidade da metrópole: A verticalização em São Paulo. São Paulo, 1989. Tese (Livre-docência) - Faculdade de Filosofia, Letras e Ciências Humanas, Universidade de São Paulo.

WERK ARCHITHESE. Grossüberbauungen. Zurique: Verlag Arthur Nigli AG, n. 5, maio 1977. Meccano?. Zurique: Verlag Arthur Nigli AG, n. 11-12, nov./dez. 1977. Stadtsanierung. Zurique: Verlag Arthur Nigli AG, n. 15-16, mar./abr. 1977.

\begin{tabular}{|c|c|c|}
\hline 70 & Paisagem & São Paulo n. 11 p. 4170 - dez. 1998 \\
\hline & $\begin{array}{l}\text { Ensaios } \\
11\end{array}$ & \\
\hline
\end{tabular}

